Review

\title{
Opposed Interplay between IDH1 Mutations and the WNT/ $\beta$-Catenin Pathway: Added Information for Glioma Classification
}

\author{
Alexandre Vallée ${ }^{1, *}$, Yves Lecarpentier ${ }^{2}$ and Jean-Noël Vallée ${ }^{3,4}$ \\ 1 Department of Clinical Research and Innovation, Foch Hospital, 92150 Suresnes, France \\ 2 Centre de Recherche Clinique, Grand Hôpital de l'Est Francilien (GHEF), 77100 Meaux, France; \\ yves.c.lecarpentier@gmail.com \\ 3 Centre Hospitalier Universitaire (CHU) Amiens Picardie, Université Picardie Jules Verne (UPJV), \\ 80000 Amiens, France; valleejn@gmail.com \\ 4 Laboratoire de Mathématiques et Applications (LMA), UMR CNRS 7348, Université de Poitiers, \\ 86000 Poitiers, France \\ * Correspondence: alexandre.g.vallee@gmail.com
}

check for updates

Citation: Vallée, A.; Lecarpentier, Y.; Vallée, J.-N. Opposed Interplay between IDH1 Mutations and the WNT/ $\beta$-Catenin Pathway: Added Information for Glioma Classification. Biomedicines 2021, 9, 619. https:// doi.org/10.3390/biomedicines9060619

Academic Editor: Sevin Turcan

Received: 4 May 2021

Accepted: 28 May 2021

Published: 30 May 2021

Publisher's Note: MDPI stays neutral with regard to jurisdictional claims in published maps and institutional affiliations.

Copyright: (c) 2021 by the authors. Licensee MDPI, Basel, Switzerland. This article is an open access article distributed under the terms and conditions of the Creative Commons Attribution (CC BY) license (https:/ / creativecommons.org/licenses/by/ $4.0 /)$.

\begin{abstract}
Gliomas are the main common primary intraparenchymal brain tumor in the central nervous system (CNS), with approximately 7\% of the death caused by cancers. In the WHO 2016 classification, molecular dysregulations are part of the definition of particular brain tumor entities for the first time. Nevertheless, the underlying molecular mechanisms remain unclear. Several studies have shown that $75 \%$ to $80 \%$ of secondary glioblastoma (GBM) showed IDH1 mutations, whereas only $5 \%$ of primary GBM have IDH1 mutations. IDH1 mutations lead to better overall survival in gliomas patients. IDH1 mutations are associated with lower stimulation of the HIF- $1 \alpha$ a, aerobic glycolysis and angiogenesis. The stimulation of HIF- $1 \alpha$ and the process of angiogenesis appears to be activated only when hypoxia occurs in IDH1-mutated gliomas. In contrast, the observed upregulation of the canonical WNT/ $\beta$-catenin pathway in gliomas is associated with proliferation, invasion, aggressiveness and angiogenesis. Molecular pathways of the malignancy process are involved in early stages of WNT/ $\beta$-catenin pathway-activated-gliomas, and this even under normoxic conditions. IDH1 mutations lead to decreased activity of the $\mathrm{WNT} / \beta$-catenin pathway and its enzymatic targets. The opposed interplay between IDH1 mutations and the canonical WNT/ $\beta$-catenin pathway in gliomas could participate in better understanding of the observed evolution of different tumors and could reinforce the glioma classification.
\end{abstract}

Keywords: gliomas; glioblastomas; WNT/ $\beta$-catenin pathway; IDH1; cancer; hypoxia; normoxia

\section{Introduction}

Gliomas are the main common primary intraparenchymal brain tumor in the central nervous system (CNS), with approximately $7 \%$ of the death caused by cancers $[1,2]$. Gliomas are composed by a very heterogeneous group of primary CNS tumors, originally classified according to their microscopic similarity with presumed origin of non-neoplastic glial cells (including astrocytes-astrocytoma; oligodendroglial cells-oligodendroglioma; 'glioblast' - glioblastoma). Gliomas are traditionally divided into two major categories: 'diffuse' gliomas and 'non-diffuse' tumors. Diffuse gliomas are characterized by tumor cell migration over large distances into the CNS parenchyma, with possible curative surgical resection. Malignancy grade was defined by the presence or the absence of marked mitotic activity, necrosis and/or florid micro- vascular proliferation. Non-diffuse gliomas are mainly much more circumscribed. Molecular mechanisms can help to categorize glial tumors into different diffuse and non-diffuse glioma entities. The tremendous increase in knowledge of the molecular characteristics of CNS tumors during the last decade has 
allowed for a paradigm shift. In the update of the 4th edition of the World Health Organization (WHO) classification CNS tumors published in 2016 [3,4], molecular dysregulations are part of the definition of particular brain tumor entities for the first time. Especially, the classification of the main frequent primary neoplasms of the CNS parenchyma itself, the diffuse gliomas, has undergone major restructuring based on the status of a few key molecular aberrations (Supplementary Materials). Nevertheless, the molecular mechanism that gliomas undergo remains unclear and needs to be clarified.

Mutations in enzymes regulating metabolite flux are implicated in gliomas development, as highlighted by the discovery of isocitrate dehydrogenase 1 (IDH1), in more than $70 \%$ of diffusely infiltrating WHO grade II and grade III astrocytic and oligodendroglial gliomas, as well as in a small fraction of glioblastomas (GBM), particularly those that develop from low-grade-gliomas (LGG) [3,5-8].

In parallel, a large number of studies have suggested that WNT signaling is aberrantly activated in GBM and that it promotes GBM growth and invasion [9-13].

However, very few studies have investigated the interplay between IDH1 mutations and WNT signaling in gliomas and thus, the repercussion in gliomas development.

IDH1 mutations have not been reported in pediatric gliomas, suggesting that IDH1 mutations are only restricted to astrocytomas and oligodendrogliomas in young adults [14-16]. Gliomas in children are predominantly driven by other mutations (with mutations at $\mathrm{K} 27 \mathrm{M}$ or G34V or G34R). The nature of these different mutations, restricted to certain ages, suggest that pediatric and young adult gliomas may have different cells of origin [17]. Thus, this review is focused on the opposed interplay between IDH1 mutations and the canonical WNT/ $\beta$-catenin in gliomas development in young adults.

\section{IDH1 Mutations and Glioma}

Glioblastomas (GBM) differ at the genetic and epigenetic levels, especially with the distinguishing feature in the identification of mutations in the metabolic enzyme isocitrate dehydrogenase 1 (IDH1). IDH1 mutations are one of the earliest detectable genetic damages in low-grade gliomas [17]. IDH1 were reported in 2008 and the mutation of the arginine at codon 132 is the main frequent type. It was also reported that $80 \%$ to $90 \%$ of IDH1 mutations in astrocytic and oligodendroglial gliomas have the type $\mathrm{R} 132 \mathrm{H}$ (arginine to histidine) [18-20]. Numerous studies showed that IDH1 mutations lead to better overall survival in gliomas patients and better response to therapies [21-24].

It was found that $75 \%$ to $80 \%$ of secondary GBM showed IDH1 mutations, whereas only $5 \%$ of primary GBM had IDH1 mutations $[17,25]$. Primary GBM were observed to have very low mutations levels in IDH1 (around $<3 \%-5 \%)$ ) [17,26]. IDH1 mutations had developed through progression from an anaplastic glioma (WHO Grade III), while the majority of secondary GBM with IDH1 mutations had progressed from a WHO Grade II glioma [19]. Moreover, to provide insights about the origin of gliomas, the mutational status of IDH1 serves as a prognostic factor in patients with WHO grade II and III gliomas [27] and GBM [28].

IDH1 is considered as a marker of secondary GBM and those primary GBMs diagnosed with IDH1 mutations may have been secondary gliomas that rapidly progressed to GBM with no early low-grade clinical symptoms experienced by patients [29]. IDH1 mutations occur early in glioma-genesis and occur in a progenitor cell that can give rise to both cell types. IDH1 mutations have not been reported in other CNS tumors including ependymomas, medulloblastomas, meningiomas, and pilocytic astrocytomas and are very rare in spinal gliomas [19,30-32]. In gliomas, the frequency of IDH1 mutations in codon 132 increases in the order R132L, R132S, R132G, R132C, to R132H, with R132H constituting more than $90 \%$ of all IDH1 mutations [21].

Somatic mutations in IDH1 genes have recently been identified in a large proportion of glial tumors of the CNS [4,21]. IDH1 mutation has been reported to be a strong and independent indicator for good prognosis in gliomas whatever the tumor grade [33]. 
IDH1 mutation was a positive prognostic marker, because patients with this mutation had significantly better overall survival [5]. Several studies also showed that patients with GBM or diffuse glioma with IDH1 mutations had better overall survival and progressionfree survival [7,34-39].

Some studies showed that patients with IDH1 mutations versus those with wild-type IDH1 possessed significantly better overall survival times when treated with surgery and radiotherapy $[40,41]$. IDH1 mutations were associated with a better response to cytotoxic therapy and longer survival in malignant glioma patients [42,43]. In comparison with IDH-mutated LGG, primary GBM (IDH wild-type GBM) and IDH wild-type LGG were characterized by a clinically aggressive behavior with a dismal prognosis $[27,44]$.

\section{Non-IDH1-Mutated Glioma}

Integrated genomic/transcriptome and epigenomic analysis resulted in a gene expressionbased molecular classification of GBM into classical, mesenchymal (MES), proneural (PN), and neural subtypes, characterized by aberrations and gene expression of the epidermal growth factor receptor (EGFR), neurofibromatosis Type 1, and platelet-derived growth factor receptor a (PDGFRa). Previous studies showed that responses to aggressive chemotherapy and radiotherapy differed according to subtype [45].

The PN subgroup was enriched for mutations in IDH1, mutation in TP53, and amplifications of PDGFRa, cyclin-dependent kinase 6 (CDK6), CDK4, and receptor for hepatocyte growth factor (Met) [17]. Moreover, this group contained the highest percentage of young patients, likely because of the enrichment of IDH1 mutations, which is associated with younger patient age. The classical subtype is characterized by EGFR amplification and a loss of phosphatase and tensin homolog (PTEN). The classical subtype also harbors the mutant EGFR variant III (EGFRvIII) mutation, which is constitutively active and has an in-frame deletion of exons 2-7. The MES subclass is associated with poor overall survival, contains neurofibromatosis Type 1 mutations, and has a loss of TP53 and CDK inhibitor N2A (CDKN2A). Last, the neural subtype has elevated levels of neural markers such as NEFL but has no unique distinguishing alterations from other classes, although elevated rates of ERBB2 mutation were observed [17].

The genomic characterization of IDH wild-type GBM reveals frequent genetic alterations of key components of the growth factor receptor-PI3K-Akt signaling pathway that activates the mechanistic target of rapamycin (mTOR) signaling [46-48]. The EGFR is a major activator of a variety of pathways and physiological responses include proliferation, survival, migration, and tumorigenesis. EGFR is amplified in about 40\% of GBM patients, and is often associated with high-grade classical tumors [25]. While it is commonly thought that amplification or mutation of EGFR is an indicator of poor survival, several studies failed to validate this conclusion [49]. Mutations and amplifications of EGFR and loss of chromosome 10 are rarely found in IDH1 mutant tumors [26].

The PI3K pathway is normally activated by the EGFR and other growth factor receptors [50]. EGFR binds PI3K/Akt/STAT and modulates proliferation, differentiation and survival [51,52]. PI3K is activated by EGFR. PI3K converts PIP2 in PIP3 [53,54]. The activity of PI3K is counteracted by PTEN, which converts PIP3 back to PIP2 [55]. PI3K activates Akt signaling by phosphorylation [56]. An increase in Akt signaling inhibits GSK-3 $\beta$ activity and leads to nuclear translocation and stability of $\beta$-catenin [53]. PI3K/Akt signaling regulates $\beta$-catenin stability, translocation, transcriptional activity and the expression of its downstream genes (such as Cyclin D1 and c-Myc) [54].

Approximately $40 \%$ of GBM have mutations in the PTEN protein and around $70 \%$ show a loss of heterozygosity at the PTEN locus [57]. The value of PTEN loss as a prognostic marker has not been validated, and is still somewhat controversial [58].

Recent studies identified a set of interlacing molecular mechanisms by which EGFRvIII, a constitutively activating mutant form of EGFR, co-opts c-Myc to reprogram cellular metabolism and drive tumor proliferation. This involves the mTOR complexes 1 and 2 (mTORC1 and mTORC2) [46,59]. Moreover, failure to inhibit mTOR signaling can render 
GBM cells resistant to PI3K/Akt-targeted therapies by maintaining elevated levels of c-Myc [59].

In EGFR-mutant GBM, which do not usually possess the mutations in IDH or $\mathrm{H} 3$ histone family $3 \mathrm{~A}(\mathrm{H} 3 \mathrm{~F} 3 \mathrm{~A})$ to potentially change the epigenetics, constitutive PI3K activation could engage the epigenetic machinery through several complementary routes. First, EGFR activation causes the glycolytic enzyme pyruvate kinase isozymes M2 (PKM2) to translocate to the nucleus, where it phosphorylates histone 3 at Thr11, causing dissociation of histone deacetylase 3 (HDAC3), and promotes histone acetylation to regulate transcription of the cancer-promoting genes, including c-Myc and cyclin D1 [60].

In approximately $30 \%$ of human gliomas, expression of genes associated with PDGFR signaling and genes involved in oligodendrocyte development (OLIG2, NKX2-2, and PDGF), are observed and are thought to be hallmarks of the PN signature in GBM [9]. Amplification of the $\alpha$-type PDGFR (PDGFRA) gene is found in 15\% of all tumors, mainly in the PN subtype of GBM $[45,61]$ and approximately $40 \%$ of tumors harboring gene amplification contain an intragenic deletion in this gene [62]. However, the expression of PDGFRB seems to be limited to proliferating endothelial cells in GBM [63,64]. Similar to EGFR and EGFRvIII, amplification of PDGF and PDGFR seems to promote aggressive glioma growth [65].

\section{Canonical WNT/ $\beta$-Catenin Pathway}

The WNT name is derived from Wingless drosophila melanogaster and its mouse homolog Int. The WNT/ $\beta$-catenin pathway is implicated in several mechanisms and controls signaling, including embryogenesis, cell proliferation, migration and polarity, apoptosis, and organogenesis [66]. Nevertheless, during several pathological diseases, the WNT/ $\beta$-catenin pathway can be altered, to impact mechanisms including inflammation, metabolic, neurological and psychiatric disorders, fibrosis and cancer processes [67].

The WNT pathway belongs to the family of secreted lipid-modified glycoproteins [68]. WNT ligands are produced by neurons and immune cells localized in the CNS [69]. WNT pathway dysfunction could affect numerous neurodegenerative pathologies [70-74]. The WNT pathway has a main stage called the $\beta$-catenin/T-cell factor/lymphoid enhancer factor (TCF/LEF). Cytoplasmic accumulation of $\beta$-catenin is modulated by the destruction complex AXIN, tumor suppressor adenomatous polyposis coli (APC), and glycogen synthase kinase-3 (GSK-3 $\beta$ ). With absence of WNT ligands, the destruction complex has a role in the hyper-phosphorylation of the cytoplasmic $\beta$-catenin and leads to its proteasomal destruction. Nevertheless, in their presence, the WNT ligands bind to Frizzled (FZL) and LDL receptor-related protein 5/6 (LRP 5/6) to interrupt the destruction complex and prevents $\beta$-catenin degradation into the proteasome. $\beta$-catenin translocates to the nucleus to interact with the TCF/LEF; this stimulates WNT target genes [75-77].

Glycogen synthase kinase-3 $\beta$ (GSK-3 $\beta$ ) is one of the major inhibitors of the WNT/ $\beta$ catenin pathway [78-83]. As an intracellular serine-threonine kinase, GSK-3 $\beta$ is a major negative controller of the WNT signaling [84]. GSK-3 $\beta$ is implicated in the control of numerous kinds of pathophysiological pathways, including cell membrane signaling, cell polarity, and inflammation [85-87]. GSK-3 $\beta$ interacts by downregulating the cytoplasmic $\beta$-catenin and stabilizing it to enhance its nuclear migration. Inflammation is an age-related mechanism correlated with the activation of GSK- $3 \beta$ pathway and the diminution of the WNT/ $\beta$-catenin pathway [88].

Recent studies have observed that glaucoma patients presented activation of the GSK-3 $\beta$ pathway and its downregulation may be an interesting therapy target $[89,90]$. Dysregulation of GSK-3 $\beta$ is implicated in the pathogenesis of numerous pathologies, such as cancer processes [91-93]. GSK-3 $\beta$ is a regulator of numerous signaling including inflammation, neuronal polarity or cell membrane signaling [86]. GSK-3 $\beta$ is known to be the major inhibitor of the canonical WNT/ $\beta$-catenin pathway [82,93-97]. 


\section{Canonical WNT/ $\beta$-Catenin Pathway in Glioma}

A large number of studies have suggested that WNT signaling is aberrantly activated in GBM and that it promotes GBM growth and invasion via the maintenance of stem cell properties [9-13]. The nuclear accumulation of $\beta$-catenin is responsible for the malignant progression and $\beta$-catenin protein levels are correlated with malignancy and with the gene expression of cyclin D1 and c-Myc [98-100]. The aberrant activation of WNT/ $\beta$-catenin pathway contributes to gliomas progression $[98,99,101-105]$ (Figure 1).

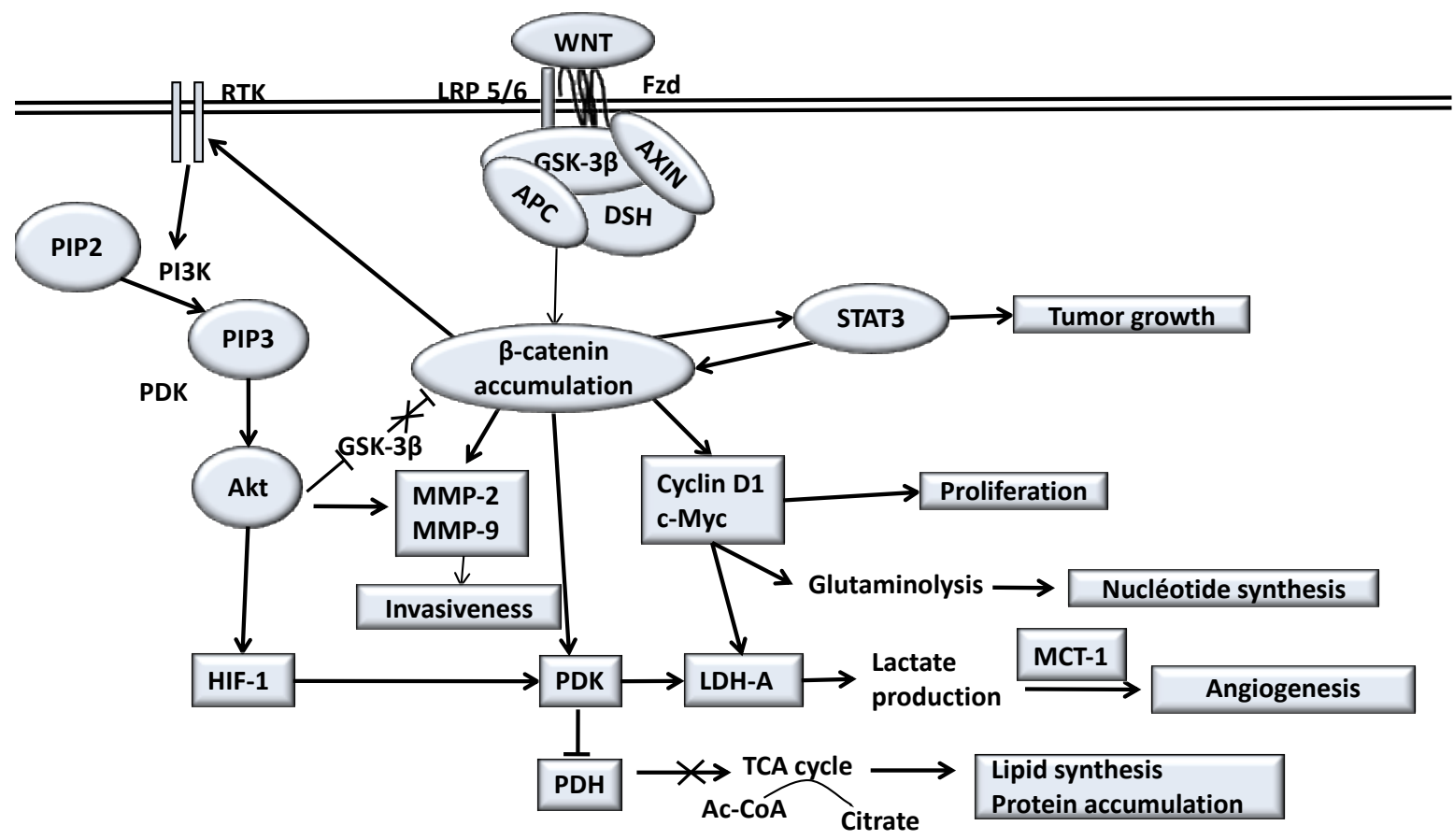

Figure 1. The WNT/ $\beta$-catenin pathway and its different actions in gliomas processes. When the canonical WNT/ $\beta$-catenin pathway is stimulated, STAT3 signaling pathway upregulates the expression and transcriptional activity of $\beta$-catenin. In cancers STAT3 is a tumor aggressiveness factor. In cancers, the overexpression of EGFR (a receptor tyrosine kinase: RTK) stimulates PI3K/Akt pathway. PI3K/Akt signaling leads to the phosphorylation of GSK-3 $\beta$ that leads to nuclear translocation and stabilization of $\beta$-catenin. Similarly, WNT/ $\beta$-catenin pathway stimulates EGFR in gliomas. Akt signaling increases MMP-2 and MMP-9 activity, which induce invasion of cancer cells. Akt signaling induces HIF-1a, which stimulates PDK1. Overexpression of WNT/ $\beta$-catenin also stimulates PDK1. PDK1 and c-Myc induce LDH-A, and cytolsolic pyruvate is shunted into lactate through activation of LDH-A. Overexpression of MCT-1 exports lactate to extracellular space. Lactate production stimulates angiogenesis. c-Myc induced glutaminolysis supports mitochondrial integrity and production of aspartate, and results in nucleotide biosynthesis. c-Myc and cyclin D stimulate proliferation of gliomas.

Recent studies have described the functions of WNT/ $\beta$-catenin pathway in development and cancer, with particular emphasis on genetic and epigenetic alterations that lead to aberrant WNT pathway activation in GBM [106-110]. Prominent genomic alterations frequently found in GBM include loss-of-function of tumor suppressors in the p53, phosphatase and tensin homolog and neurofibromatosis 1 , and hyperactivation of receptor tyrosine kinase (RTK) signaling, including EGFR, PDGF receptor, and the receptor for hepatocyte growth factor (Met) [3].

Epigenetic silencing of negative effectors of WNT pathways can activate WNT signaling and contribute to malignant behavior in GBM. Soluble Frizzled-related proteins (FRPs) are soluble proteins that bind to WNT and interfere with WNT signaling. Dickkopf (DKK) acts as an antagonist of WNT signaling via binding to its co-receptor LRP [111]. Notably, epigenetic silencing of WNT pathway inhibitor genes frequently occurs in gliomas, including promoter hyper-methylation of sFRPs, Dickkopf-1 and Naked (NKD1, NKD2). 
In GBM, promoter hypermethylation of sFRP1, sFRP2 and NKD2 occurred in more than $40 \%$ of primary GBM specimens [112,113].

Epithelial-mesenchymal transition (EMT) is a critical process that enables cancer cells of epithelial origin to metastasize to distal organs. Unsurprisingly, WNT signaling is involved in both tumor invasion and EMT [12]. FZD4, a positive WNT regulator, was identified and shown to be a causative effector for invasive phenotypes of GBM cells [114].

Receptor tyrosine kinases (RTKs) promote GBM survival, proliferation, and invasion. Hyperactivation of RTK signaling because of genomic amplification and/or activating mutations of RTKs occurs in more than 90\% of GBMs [45]. Amplifications or somatic mutations in EGFR, PDGF receptor, FGFR, and Met often correlate with GBM subtypes [45].

Activation of EGFR induces downstream mitogenic signaling, such as the mitogenactivated protein kinase, PI3K/Akt, and transducers and activators of transcription (STAT) pathways [115,116]. WNT pathway can induce activation of the Akt pathway [117].

Met has crucial roles in cancer growth, stem cell maintenance, and metastasis [118]. In GBM, expression levels of Met correspond with poor patient survival and malignancy [119]. In addition, analyses of clinical GBM specimens revealed a positive association between Met expression and invasiveness-related genes (matrix metalloproteinases: MMP2 and MMP9) and proto-oncogenes (c-Myc, KRAS, and JUN) [120,121]. Activation of Met signaling can be enabled by the addition of hepatocyte growth factor (HGF)-induced nuclear translocation of $\beta$-catenin [122].

\section{Opposed Interplay between IDH1 Mutations and WNT/ $\beta$-Catenin Pathway in Glioma}

A recent study reported that the IDH1-R132H mutation causes both a less aggressive phenotype and radiosensitization of human malignant glioma cells [123]. Metastasis in cancer is initiated by a process called EMT transition that requires upregulation of $\beta$-catenin, the mediator of the canonical WNT pathway [124,125]. IDH1-R132H mutation leads to decreased activity of WNT/ $\beta$-catenin pathway, that in turn curbs the elevated proliferation and migration observed in invasive gliomas [126]. The expression of mediators, effectors and targets of the canonical WNT pathway, including $\beta$-catenin, TCF4 and LEF1 is downregulated in glioma cells overexpressing IDH1-R132H [126]. In addition, negative regulators of WNT/ $\beta$-catenin pathway, such as DKK1 and APC, are upregulated in these cells. The activity of the endpoint mediator of this pathway, TCF, is significantly downregulated in IDH1-R132H cells [126]. Thus, IDH1-R132H causes a significant reduction in the proliferation, migration and invasiveness of gliomas, accompanied by an increase in apoptotic cell death [127].

Glioma cells overexpressing IDH1-R132H displayed higher chemosensitivity due to increased generation of reactive oxygen species (ROS) and depletion of glutathione, suggesting that they respond better to chemotherapy than IDH1-wt gliomas [127,128].

The PI3K/Akt pathway is upregulated in invasive gliomas in association with the $\mathrm{WNT} / \beta$-catenin pathway $[92,129]$, and is known to induce tumor progression [130]. IDH1R132H decreases the activity of the PI3K/Akt pathway in glioma cells [131]. Mutated IDH1 thus blocks PI3K/Akt signaling, a pathway associated with the development of a more aggressive glioma phenotype [132,133].

Recent studies have shown that the presence of IDH1-R132H mutation is associated with a better prognosis in glioma patients in association to the decrease in the expression of the WNT/ $\beta$-catenin pathway [134]. Yao et al. demonstrated that IDH1 mutation diminished the malignant progression of glioma by causing a less aggressive phenotype of GSCs, which were involved in the WNT/ $\beta$-catenin pathway [126,134]. Furthermore, IDH1 mutation is associated with the reduction in cell survival, proliferation and invasion of glioma by decreasing the WNT signaling $[126,135]$ (Table 1). 
Table 1. Opposed interplay between the WNT pathway and IDH1 mutations and the involved molecular targets.

\begin{tabular}{|c|c|c|c|c|c|}
\hline Marker & Cell Pathways & Regulation & Subtypes & Prognosis & References \\
\hline IDH1 mutations & $\begin{array}{l}\text { NADPH-dependent } \\
\text { reduction of } \\
\text { alpha-ketoglutarate }\end{array}$ & $\begin{array}{l}\text { HIF- } 1 \alpha \text { reduction } \\
\text { activity }\end{array}$ & Glioblastoma & Good survival rate & [136] \\
\hline IDH1 mutations & $\begin{array}{l}\text { TP } 53 \text { and total } 1 \mathrm{p} / 19 \mathrm{q} \\
\text { deletions }\end{array}$ & - & $\begin{array}{l}\text { Oligodendroglia } \\
\text { tumors }\end{array}$ & Good survival rate & [26] \\
\hline $\begin{array}{l}\text { IDH1-R132H } \\
\text { mutation }\end{array}$ & $\begin{array}{l}\beta \text {-catenin, TCF4 and } \\
\text { LEF1 downregulation }\end{array}$ & $\begin{array}{l}\text { Decrease WNT } \\
\text { signaling }\end{array}$ & Glioma cells & Lower invasion & {$[126,134]$} \\
\hline $\begin{array}{l}\text { IDH1-R132H } \\
\text { mutation }\end{array}$ & $\begin{array}{l}\text { PI3K/Akt pathway } \\
\text { decrease }\end{array}$ & $\begin{array}{l}\text { Decrease WNT } \\
\text { signaling }\end{array}$ & Glioma cells & Good survival rate & [131-133] \\
\hline IDH1 mutations & $\begin{array}{l}\text { HIF-1 } \alpha \text { reduction } \\
\text { activity }\end{array}$ & $\begin{array}{l}\text { Decrease WNT } \\
\text { signaling }\end{array}$ & $\begin{array}{l}\text { Restricted to } \\
\text { necrotic areas }\end{array}$ & Poor survival rate & [137-139] \\
\hline EGFR & $\begin{array}{l}\beta \text {-catenin } \\
\text { accumulation }\end{array}$ & $\begin{array}{l}\text { Increase WNT } \\
\text { signaling }\end{array}$ & Astrocytomas & $\begin{array}{l}\text { Glioma } \\
\text { progression and } \\
\text { invasion }\end{array}$ & {$[98,99,101-105]$} \\
\hline sFRP1 depletion & $\begin{array}{l}\beta \text {-catenin } \\
\text { accumulation }\end{array}$ & $\begin{array}{l}\text { Increase WNT } \\
\text { signaling }\end{array}$ & Glioblastoma & $\begin{array}{l}\text { Inhibit Motility } \\
\text { and Promote } \\
\text { Growth }\end{array}$ & {$[112,113]$} \\
\hline RTKs & WNT signaling & IDH1 decrease & Glioblastoma & & [45] \\
\hline
\end{tabular}

\section{Oxidative Stress and IDH1 Mutations in Glioma}

Previous studies showed that elevated levels in tumor cells of reactive oxygen species (ROS) led to cell cycle arrest, inhibition of proliferation and promotion of apoptosis, thereby decreasing tumor growth $[140,141]$. An imbalance between the production of ROS and the ability of the cellular antioxidant system to readily detoxify ROS led to oxidative stress [142,143]. Glutathione (GSH) is the most abundant intracellular antioxidant, and is involved in the protection of cells against oxidative damage and in various detoxification mechanisms [144]. Diminution of intracellular GSH levels results in the accumulation of ROS in cells, and elevated levels are associated with apoptosis resistance [145]. Nicotinamide adenine dinucleotide phosphate (NADPH) is an essential cofactor for the biosynthesis of GSH, and the oxidized form of glutathione, GSSG, is reduced to GSH in an NADPH-dependent reaction catalyzed by glutathione reductase [146].

IDH1 catalyzes the oxidative carboxylation of isocitrate to a-ketoglutarate, yielding reduced NADPH [141]. In gliomas, IDH1 mutations decreased the intracellular GSH levels, enhanced the levels of intracellular ROS and inhibited the growth of glioma cells [141]. Overexpression of mutant IDH1 in glioma cells resulted in an increase in intracellular ROS levels, showing that the mutant IDH1 affected growth inhibition by induction of cell apoptosis and inhibition of proliferation [128]. Thus, NADPH levels are diminished in IDH1-R132H gliomas in situ [136].

\section{Hypoxia in IDH1-Mutated Glioma}

Tumor hypoxia results in constitutive upregulation of glycolysis and acidosis, contributing to the tumor resistance of therapeutic agents [147]. The progression of gliomagenesis often occurs in a hypoxic microenvironment that compels the use of anaerobic glycolysis as the primary energy source [148]. Hypoxia stabilizes HIF, a transcription factor, which increases the biological aggressiveness of tumors, promoting glycolysis, cellular proliferation, and angiogenesis $[149,150]$. Once activated, HIF- $1 \alpha$ can regulate the expression of many glycolytic enzymes including glucose transporters and mitochondrial enzymes that are involved in the metabolic adaptation to hypoxia through the conversion of glucose to pyruvate and subsequently to lactate [151]. Hypoxia in solid tumors plays an important role in the propagation of a cascade of molecular pathways in favor of tumor growth [152]. Hypoxia-induced HIFs stimulate angiogenesis and increase malignancy, metastasis, and resistance to therapy [153]. HIF-1 $\alpha$ is one of the key factors that regulates the expression of VEGF, which plays an important role in angiogenesis in gliomas [154]. 
IDH1-related low-grade and anaplastic gliomas were not associated with an activation of HIF- $1 \alpha$ and HIF-1 $\alpha$ overexpression was restricted to necrotic areas [137-139]. IDH1 mutations and 2HG production were shown to inhibit prolyl-hydroxylase (PHD) enzymes, which inhibit HIF-1a, the major pro-angiogenic and pro-glycolysis transcription factor $[155,156]$.

\section{Aerobic Glycolysis and WNT/ $\beta$-catenin Pathway in Glioma}

Glucose is the major source of energy for mammalian cells. Glucose is metabolized to produce ATP (energy), through cytosolic glycolysis and oxygen-dependent mitochondrial metabolism. The entry of glucose into the TCA cycle is controlled by PDH (pyruvate dehydrogenase complex). Inhibition of PDH inactivates mitochondrial activity in gliomas [157]. A large part of the glucose supply is fermented to lactate; this phenomenon is called aerobic glycolysis or the Warburg effect [158].

Growing evidence reveals that all cancers, regardless of tissue or cellular origin, are a disease of impaired cellular energy metabolism [159]. In addition to the previously well recognized hallmarks of cancers [160-162], aerobic glycolysis is also a robust metabolic feature of most tumors $[160,163,164]$. Recent studies on gliomas in experimental models show the dependence of glioma cells on glycolysis as the primary source of energy [165]. Glioma cells are dependent on glycolysis for their primary source of energy [165], with upregulation of glycolytic metabolism [166,167]. Cancer cells can use aerobic glycolysis at all oxygen levels (i.e., normoxia, hypoxia, or hyperbaric oxygen) [168].

\section{Normoxia and $W N T / \beta$-catenin Pathway Upregulation in Glioma}

In cancer cells, early overexpression of the $\mathrm{WNT} / \beta$-catenin pathway leads to induce aerobic glycolysis [169] (Figure 2).

In addition, WNT target genes, c-Myc and cyclin D1, also activate aerobic glycolysis [170]. c-Myc and PI3K/Akt signaling overexpression induces HIF-1 $\alpha$ activation, which suppresses glucose entry into the TCA cycle [171,172]. Activation of canonical WNT signaling directly acts on aerobic glycolysis [173] and increases vessel development via the WNT target genes [174]. Activation of the canonical WNT/ $\beta$-catenin pathway suppresses oxidative metabolism into the TCA cycle and promotes cell proliferation [174]. The WNT pathway induces the transcription of genes implicated in cell proliferation, c-Myc (through glutaminolysis, nucleotide synthesis and lactate dehydrogenase-A (LDH-A) activation) and cyclin-D1 (through G1) [170,175-179]. The WNT target gene c-Myc drives aerobic glycolysis and glutaminolysis [171,177]. c-Myc induces glutamine uptake into the cell and the mitochondria and favors aspartate synthesis [170].

WNT/ $\beta$-catenin pathway stimulates RTK (such as PI3K signaling) activation in gliomas [180]. Downregulation of $\beta$-catenin reduces the expression of EGFR, Akt signaling and their downstream genes [181-184]. Aerobic glycolysis also occurs via PI3K/Akt signaling in cancer cells, glucose is taken up in excess and rewired towards protein and lipid synthesis [185-187], which induces cellular growth. Hyper activation of PI3K/Akt pathway is associated with an increased rate of glucose metabolism [188]. Under normoxic conditions, activation of the $\mathrm{qPI} 3 \mathrm{~K} / \mathrm{Akt}$ pathway results in HIF-1 $\alpha$ stimulation [189].

Phosphorylated STAT3 by IL-6 (interleukin 6) or LIF (leukemia inhibitory factor) is associated with overexpression of HIF-1 $\alpha$ under normoxic conditions [190]. B-catenin/TCF4 complex directly binds to the STAT3 gene promoter [191]. STAT pathways participate in tumorigenesis through up-regulation of genes encoding cell-cycle regulators (cyclin D1, c-Myc) and induces activation of VEGF [192]. 


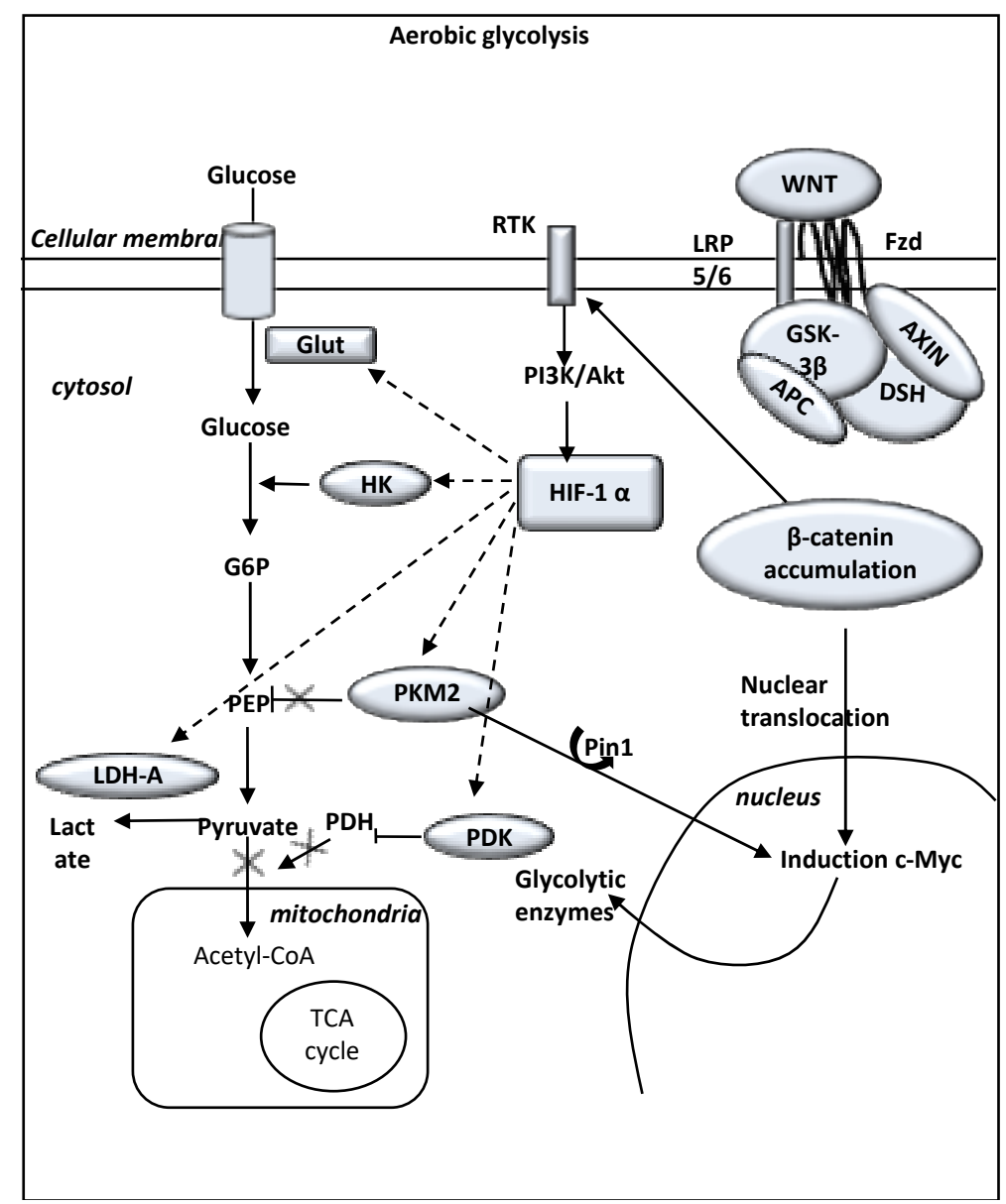

Figure 2. The WNT/ $\beta$-catenin pathway and the Warburg effect (i.e., aerobic glycolysis). WNT ligands bind the complex Frizzled/LRP 5/6 receptors leading to LRP phosphorylation of the AXIN/APC/GSK-3 $\beta$ complex. $\beta$-catenin phosphorylation is inhibited and this prevents its degradation in the proteasome. $\beta$-catenin accumulates into the cytosol and then translocates to the nucleus to bind TCF-LEF co transcription factors. WNT-response gene transcription is stimulated (PDK, c-Myc, cyclin D, MCT-1). MCT-1 promotes the release of lactate out of the cell. WNT/ $\beta$-catenin pathway activates tyrosine kinase receptors (TKRs). Activation of PI3K/Akt increases glucose metabolism. Akt-transformed cells induce HIF-1 $\alpha$ stabilization, which largely diminishes the glucose entry into the TCA cycle. Stimulated HIF-1 $\alpha$ activity increases expression of glycolytic enzymes (GLUT, HK, PKM2, LDH-A). Elevated aerobic glycolysis is observed with increased production of lactate and decreased mitochondrial respiration. HIF-1 $\alpha$ induced PDK phosphorylates PDH, which results in cytosolic pyruvate being shunted into lactate through induction of LDH-A. PDK inhibits the PDH complex into mitochondria. Thus, pyruvate cannot be fully converted into acetyl-CoA and enter the TCA cycle. c-Myc and cyclin D also activate LDH-A, which converts cytosolic pyruvate into lactate. Activated PKM2 translocates to the nucleus through Pin1, then binds $\beta$-catenin and induces c-Myc expression. This activates GLUT, PKM2 and LDH-A in a positive feedback.

It has been reported that HIF-1 $\alpha$ can be activated by numerous oncogenes even under normoxic conditions (independent of hypoxia) [186,193-195]. HIF-1 $\alpha$ is induced transcriptionally by PI3K/mTOR even under normoxic conditions through 4E-BP1 and STAT3 [190,196-200]. PI3K activates mTORC1 through Akt which inhibits by phosphorylation the tuberous sclerosis complex (TSC) [201,202]. mTOR-mediated HIF-1 $\alpha$ induction mimics the effect of hypoxia and then leads to glycolysis [189]. Several genetic mutations (such as mutated genes encoding PDGFR, EGFR, p53, and PTEN) result in HIF-1 $\alpha$ stabilization resulting in increased angiogenesis by upregulation of angiogenic factors [203-207]. HIF- $1 \alpha$ activated initiates the transcription of target genes including glucose transporters, 
the MCT-4 and key pro-angiogenic effectors such as VEGF $[149,208]$. HIF-1 $\alpha$ also promotes both glycolytic energy metabolism and angiogenesis and participates in the poor cancer prognosis [209,210].

c-Myc overexpression can also enhance LDH-A expression by promoting HIF-1 $\alpha$ stabilization under normoxic conditions [211]. c-Myc cooperates with HIF-1 $\alpha$ in activating several genes that encode glycolytic proteins, such as LDH-A [212]. LDH-A activation is associated with activation of the VEGF pathway [213-216].

Cancers cells use LDH-A to elevate the rate of glycolysis, ATP and lactate production [217]. HIF- $1 \alpha$ and c-Myc are the major transcription factors of LDH-A [218-221]. Overexpression of HIF- $1 \alpha$ is associated with LDH-A overexpression and poor survival in many cancers [215,222]. LDH-A activation is associated with activation of the VEGF pathway [213-216]. A high level of cytoplasmic LDH-A is correlated with cytoplasmic VEGF expression [215]. This association could be partly due to transcription factors HIF-1 $\alpha$ and c-Myc [211]. Lactate plays an important role in angiogenesis, by stimulation of VEGF [223-225]. In gliomas, lactate also triggers HIF-1 $\alpha$ activation in a hypoxia-independent manner by inhibition of HIF- $1 \alpha$ proline hydroxylation [226]. Lactate stimulates HIF-1 $\alpha$ activity in normoxic endothelial cells resulting in an increase of pro-angiogenic targets such as VEGFR2 [227]. VEGFR2 is the main transducer of pro-angiogenic effects of VEGF [228]. Lactate that arose from aerobic glycolysis induces the VEGF/VEGFR2 signaling pathway in a hypoxia-independent manner [229]. Acute acidic extracellular $\mathrm{pH}$, which can be caused by elevated lactate production, was shown to promote upregulation of IL-8 and VEGF independently of hypoxia [230-235]. Lactate overexpression promotes angiogenesis [236] and increased extracellular lactate concentrations activates the VEGF pathway [237]. VEGF expression in glioma cells is independently regulated by $\mathrm{pH}$ and tissue $\mathrm{pO} 2$ [231]. Hypoxia and acidic $\mathrm{pH}$ have no synergistic effect on VEGF transcription [231].

\section{Conclusions}

The majority of IDH wild-type glioblastomas refer to primary glioblastomas which occur in elderly patients and develop de novo. IDH-wild-type glioblastomas usually present short clinical history, without a pre-existing lower-grade precursor lesion. They are characterized by the upregulation of the $\mathrm{WNT} / \beta$-catenin pathway showing an early tumor development under normoxic conditions for the main part [129]. In contrast, IDH mutant glioblastomas are typically observed in young adults and include the majority of secondary glioblastomas developed by the progression from a pre-existing diffuse or anaplastic astrocytoma [238]. The distinction of "IDH wild-type/WNT upregulated" and "IDH mutant/WNT downregulated" glioblastomas is major as these differences are not only biologically distinct subtypes but also associated with different clinical presentations, such as age and survival rate, with significantly shorter overall survival observed in patients with "IDH wild-type/WNT upregulated" glioblastoma [28]. Thus, opposed $\mathrm{WNT} / \beta$-catenin pathway expression is observed between IDH wild-type and IDH mutant glioblastomas and this could be included in gliomas classification (Figure 3). 


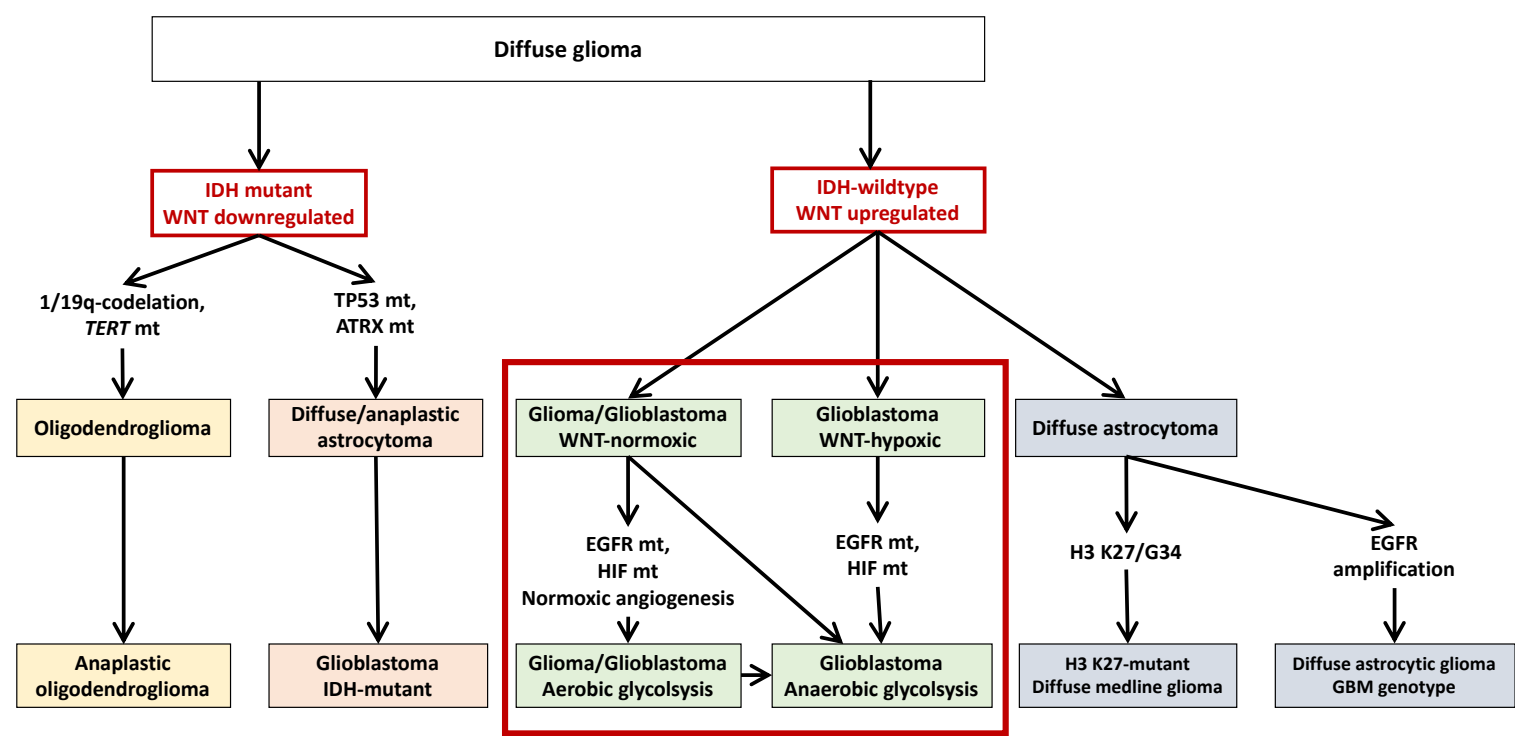

Figure 3. Features of diffuse glioma. In the $2016 \mathrm{WHO}$ classification, diffuse astrocytic tumors and oligodendrogliomas can be defined by mutually exclusive genotypes (astrocytic, TP53 mt/ATRX mt; oligodendroglial, 1p/19q-codel/TERT $\mathrm{mt}$ ) under the shared IDH mutation. IDH-wildtype tumors represent the main malignant glioblastoma or diffuse glioma genetically corresponding to glioblastoma. Our hypothesis is to add to this classification the notion of WNT pathway expression. IDH-mutant presents downregulation of the WNT pathway whereas IDH-wild-type presents upregulation of the WNT pathway. WNT pathway stimulation in the early stages of the tumor process is associated with normoxic glioma development with early angiogenesis process.

Supplementary Materials: The following are available online at https:/ /www.mdpi.com/article/10 .3390/biomedicines9060619/s1.

Author Contributions: Conceptualization, A.V. and J.-N.V.; validation, A.V., Y.L. and J.-N.V.; writingoriginal draft preparation, A.V.; writing—review and editing, Y.L. and J.-N.V.; All authors have read and agreed to the published version of the manuscript.

Funding: This research received no external funding.

Institutional Review Board Statement: Not applicable.

Informed Consent Statement: Not applicable.

Conflicts of Interest: The authors declare no conflict of interest.

\section{References}

1. Furnari, F.B.; Fenton, T.; Bachoo, R.M.; Mukasa, A.; Stommel, J.M.; Stegh, A.; Hahn, W.C.; Ligon, K.L.; Louis, D.N.; Brennan, C.; et al. Malignant astrocytic glioma: Genetics, biology, and paths to treatment. Genes Dev. 2007, 21, 2683-2710. [CrossRef]

2. Gladson, C.L.; Prayson, R.A.; Liu, W. (Michael) The Pathobiology of Glioma Tumors. Annu. Rev. Pathol. Mech. Dis. 2010, 5, 33-50. [CrossRef] [PubMed]

3. Louis, D.N.; Perry, A.; Reifenberger, G.; Von Deimling, A.; Figarella-Branger, D.; Cavenee, W.K.; Ohgaki, H.; Wiestler, O.D.; Kleihues, P.; Ellison, D.W. The 2016 World Health Organization Classification of Tumors of the Central Nervous System: A summary. Acta Neuropathol. 2016, 131, 803-820. [CrossRef] [PubMed]

4. Kristensen, B.; Priesterbach-Ackley, L.; Petersen, J.; Wesseling, P. Molecular pathology of tumors of the central nervous system. Ann. Oncol. 2019, 30, 1265-1278. [CrossRef] [PubMed]

5. Parsons, D.W.; Jones, S.; Zhang, X.; Lin, J.C.-H.; Leary, R.J.; Angenendt, P.; Mankoo, P.; Carter, H.; Siu, I.-M.; Gallia, G.L.; et al. An Integrated Genomic Analysis of Human Glioblastoma Multiforme. Science 2008, 321, 1807-1812. [CrossRef] [PubMed]

6. Arita, H.; Narita, Y.; Yoshida, A.; Hashimoto, N.; Yoshimine, T.; Ichimura, K. IDH1/2 mutation detection in gliomas. Brain Tumor Pathol. 2014, 32, 79-89. [CrossRef]

7. Liu, Y.; Lang, F.; Chou, F.-J.; Zaghloul, K.A.; Yang, C. Isocitrate Dehydrogenase Mutations in Glioma: Genetics, Biochemistry, and Clinical Indications. Biomedicines 2020, 8, 294. [CrossRef]

8. Ülgen, E.; Karacan, S.; Gerlevik, U.; Can, O.; Bilguvar, K.; Oktay, Y.; Akyerli, C.B.; Yüksel, Ş.K.; Danyeli, A.E.; Tihan, T.; et al. Mutations and Copy Number Alterations in IDH Wild-Type Glioblastomas Are Shaped by Different Oncogenic Mechanisms. Biomedicines 2020, 8, 574. [CrossRef] 
9. Brennan, C.; Momota, H.; Hambardzumyan, D.; Ozawa, T.; Tandon, A.; Pedraza, A.; Holland, E. Glioblastoma Subclasses Can Be Defined by Activity among Signal Transduction Pathways and Associated Genomic Alterations. PLoS ONE 2009, 4, e7752. [CrossRef]

10. Gong, A.; Huang, S. FoxM1 and Wnt/ $\beta$-Catenin Signaling in Glioma Stem Cells. Cancer Res. 2012, 72, 5658-5662. [CrossRef]

11. Yu, C.-Y.; Liang, G.-B.; Du, P.; Liu, Y.-H. Lgr4 Promotes Glioma Cell Proliferation through Activation of Wnt Signaling. Asian Pac. J. Cancer Prev. 2013, 14, 4907-4911. [CrossRef]

12. Lee, Y.; Lee, J.-K.; Ahn, S.H.; Lee, J.; Nam, D.-H. WNT signaling in glioblastoma and therapeutic opportunities. Lab. Investig. 2015, 96, 137-150. [CrossRef] [PubMed]

13. Tao, B.; Song, Y.; Wu, Y.; Yang, X.; Peng, T.; Peng, L.; Xia, K.; Xia, X.; Chen, L.; Zhong, C. Matrix stiffness promotes glioma cell stemness by activating BCL9L/Wnt/ $\beta$-catenin signaling. Aging 2021, 13, 5284-5296. [CrossRef]

14. Schwartzentruber, J.; Korshunov, A.; Liu, X.-Y.; Jones, D.T.W.; Pfaff, E.; Jacob, K.; Sturm, D.; Fontebasso, A.M.; Quang, D.-A.K.; Tönjes, M.; et al. Driver mutations in histone H3.3 and chromatin remodelling genes in paediatric glioblastoma. Nat. Cell Biol. 2012, 482, 226-231. [CrossRef]

15. Sturm, D.; Witt, H.; Hovestadt, V.; Khuong-Quang, D.-A.; Jones, D.T.W.; Konermann, C.; Pfaff, E.; Tönjes, M.; Sill, M.; Bender, S.; et al. Hotspot Mutations in H3F3A and IDH1 Define Distinct Epigenetic and Biological Subgroups of Glioblastoma. Cancer Cell 2012, 22, 425-437. [CrossRef] [PubMed]

16. Wu, G.; Broniscer, A.; McEachron, T.A.; Lu, C.; Paugh, B.S.; Becksfort, J.; Qu, C.; Ding, L.; Huether, R.; Parker, M.; et al. Somatic histone $\mathrm{H} 3$ alterations in pediatric diffuse intrinsic pontine gliomas and non-brainstem glioblastomas. Nat. Genet. 2012, 44, 251-253. [PubMed]

17. Agnihotri, S.; Aldape, K.D.; Zadeh, G. Isocitrate dehydrogenase status and molecular subclasses of glioma and glioblastoma. Neurosurg. Focus 2014, 37, E13. [CrossRef] [PubMed]

18. Balss, J.; Meyer, J.; Mueller, W.; Korshunov, A.; Hartmann, C.; Von Deimling, A. Analysis of the IDH1 codon 132 mutation in brain tumors. Acta Neuropathol. 2008, 116, 597-602. [CrossRef]

19. Nobusawa, S.; Watanabe, T.; Kleihues, P.; Ohgaki, H. IDH1 Mutations as Molecular Signature and Predictive Factor of Secondary Glioblastomas. Clin. Cancer Res. 2009, 15, 6002-6007. [CrossRef]

20. Watanabe, T.; Nobusawa, S.; Kleihues, P.; Ohgaki, H. IDH1 Mutations Are Early Events in the Development of Astrocytomas and Oligodendrogliomas. Am. J. Pathol. 2009, 174, 1149-1153. [CrossRef]

21. Ducray, F.; Marie, Y.; Sanson, M. IDH1 and IDH2 Mutations in Gliomas. N. Engl. J. Med. 2009, 360, 2248-2249, author reply 2249. [PubMed]

22. Songtao, Q.; Lei, Y.; Si, G.; Yanqing, D.; Huixia, H.; Xuelin, Z.; Lanxiao, W.; Fei, Y. IDH mutations predict longer survival and response to temozolomide in secondary glioblastoma. Cancer Sci. 2012, 103, 269-273. [CrossRef]

23. Tesileanu, C.M.S.; Dirven, L.; Wijnenga, M.M.J.; Koekkoek, J.A.F.; Vincent, E.A.J.P.; Dubbink, H.J.; Atmodimedjo, P.N.; Kros, J.M.; van Duinen, S.G.; Smits, M.; et al. Survival of diffuse astrocytic glioma, IDH1/2 wildtype, with molecular features of glioblastoma, WHO grade IV: A confirmation of the cIMPACT-NOW criteria. Neuro-Oncology 2020, 22, 515-523. [CrossRef] [PubMed]

24. Franceschi, E.; De Biase, D.; Di Nunno, V.; Pession, A.; Tosoni, A.; Gatto, L.; Tallini, G.; Visani, M.; Lodi, R.; Bartolini, S.; et al. IDH1 Non-Canonical Mutations and Survival in Patients with Glioma. Diagnostics 2021, 11, 342. [CrossRef] [PubMed]

25. Ludwig, K.; Kornblum, H.I. Molecular markers in glioma. J. Neuro-Oncology 2017, 134, 505-512. [CrossRef] [PubMed]

26. Ichimura, K.; Pearson, D.M.; Kocialkowski, S.; Bäcklund, L.M.; Chan, R.; Jones, D.T.W.; Collins, V.P. IDH1 mutations are present in the majority of common adult gliomas but rare in primary glioblastomas. Neuro-Oncology 2009, 11, 341-347. [CrossRef]

27. Aldape, K.; Zadeh, G.; Mansouri, S.; Reifenberger, G.; Von Deimling, A. Glioblastoma: Pathology, molecular mechanisms and markers. Acta Neuropathol. 2015, 129, 829-848. [CrossRef]

28. Weller, M.; Felsberg, J.; Hartmann, C.; Berger, H.; Steinbach, J.P.; Schramm, J.; Westphal, M.; Schackert, G.; Simon, M.; Tonn, J.C.; et al. Molecular Predictors of Progression-Free and Overall Survival in Patients with Newly Diagnosed Glioblastoma: A Prospective Translational Study of the German Glioma Network. J. Clin. Oncol. 2009, 27, 5743-5750. [CrossRef]

29. Ohgaki, H.; Burger, P.; Kleihues, P. Definition of Primary and Secondary Glioblastoma-Response. Clin. Cancer Res. 2014, 20, 2013. [CrossRef]

30. Jones, D.T.W.; Jäger, N.; Kool, M.; Zichner, T.; Hutter, B.; Sultan, M.; Cho, Y.-J.; Pugh, T.J.; Hovestadt, V.; Stütz, A.M.; et al. Dissecting the genomic complexity underlying medulloblastoma. Nat. Cell Biol. 2012, 488, 100-105. [CrossRef]

31. Jones, D.T.W.; Hutter, B.; Jäger, N.; Korshunov, A.; Kool, M.; Warnatz, H.-J.; Zichner, T.; Lambert, S.R.; Ryzhova, M.; Quang, D.A.K.; et al. Recurrent Somatic Alterations of FGFR1 and NTRK2 in Pilocytic Astrocytoma. Nat. Genet. 2013, 45, 927-932. [CrossRef] [PubMed]

32. Northcott, P.A.; Shih, D.J.H.; Peacock, J.; Garzia, L.; Morrissy, A.S.; Zichner, T.; Stütz, A.M.; Korshunov, A.; Reimand, J.; Schumacher, S.E.; et al. Subgroup-specific structural variation across 1,000 medulloblastoma genomes. Nat. Cell Biol. 2012, 488, 49-56. [CrossRef]

33. Bhavya, B.; Anand, C.R.; Madhusoodanan, U.K.; Rajalakshmi, P.; Krishnakumar, K.; Easwer, H.V.; Deepti, A.N.; Gopala, S. To be wild or Mutant: Role of Isocitrate Dehydrogenase 1 (IDH1) and 2-Hydroxy Glutarate (2-HG) in Gliomagenesis and Treatment Outcome in Glioma. Cell. Mol. Neurobiol. 2019, 40, 53-63. [CrossRef] [PubMed] 
34. Dubbink, H.J.; Taal, W.; Van Marion, R.; Kros, J.M.; Van Heuvel, I.; Bromberg, J.E.; Zonnenberg, B.A.; Zonnenberg, C.B.L.; Postma, T.J.; Gijtenbeek, J.M.M.; et al. IDH1 mutations in low-grade astrocytomas predict survival but not response to temozolomide. Neurology 2009, 73, 1792-1795. [CrossRef]

35. Hartmann, C.; Hentschel, B.; Wick, W.; Capper, D.; Felsberg, J.; Simon, M.; Westphal, M.; Schackert, G.; Meyermann, R.; Pietsch, T.; et al. Patients with IDH1 wild type anaplastic astrocytomas exhibit worse prognosis than IDH1-mutated glioblastomas, and IDH1 mutation status accounts for the unfavorable prognostic effect of higher age: Implications for classification of gliomas. Acta Neuropathol. 2010, 120, 707-718. [CrossRef]

36. Gorovets, D.; Kannan, K.; Shen, R.; Kastenhuber, E.R.; Islamdoust, N.; Campos, C.; Pentsova, E.; Heguy, A.; Jhanwar, S.C.; Mellinghoff, I.K.; et al. IDH Mutation and Neuroglial Developmental Features Define Clinically Distinct Subclasses of Lower Grade Diffuse Astrocytic Glioma. Clin. Cancer Res. 2012, 18, 2490-2501. [CrossRef] [PubMed]

37. Tan, A.C.; Ashley, D.M.; López, G.Y.; Malinzak, M.; Friedman, H.S.; Khasraw, M. Management of glioblastoma: State of the art and future directions. CA Cancer J. Clin. 2020, 70, 299-312. [CrossRef]

38. Franceschi, E.; De Biase, D.; Di Nunno, V.; Pession, A.; Tosoni, A.; Gatto, L.; Lodi, R.; Tallini, G.; Visani, M.; Bartolini, S.; et al. IDH1105GGT single nucleotide polymorphism improves progression free survival in patients with IDH mutated grade II and III gliomas. Pathol. Res. Pract. 2021, 221, 153445. [CrossRef]

39. Tesileanu, C.M.S.; Vallentgoed, W.R.; Sanson, M.; Taal, W.; Clement, P.M.; Wick, W.; Brandes, A.A.; Baurain, J.F.; Chinot, O.L.; Wheeler, H.; et al. Non-IDH1-R132H IDH1/2 mutations are associated with increased DNA methylation and improved survival in astrocytomas, compared to IDH1-R132H mutations. Acta Neuropathol. 2021, 141, 945-957. [CrossRef]

40. Kessler, J.; Hohmann, T.; Güttler, A.; Petrenko, M.; Ostheimer, C.; Hohmann, U.; Bache, M.; Dehghani, F.; Vordermark, D. Radiosensitization and a Less Aggressive Phenotype of Human Malignant Glioma Cells Expressing Isocitrate Dehydrogenase 1 (IDH1) Mutant Protein: Dissecting the Mechanisms. Cancers 2019, 11, 889. [CrossRef]

41. Gülten, G.; Yalçın, N.; Baltalarlı, B.; Doğu, G.; Acar, F.; Doğruel, Y. The importance of IDH1, ATRX and WT-1 mutations in glioblastoma. Pol. J. Pathol. 2020, 71, 127-137. [CrossRef] [PubMed]

42. Weller, M.; Weber, R.; Willscher, E.; Riehmer, V.; Hentschel, B.; Kreuz, M.; Felsberg, J.; Beyer, U.; Löffler-Wirth, H.; Kaulich, K.; et al. Molecular classification of diffuse cerebral WHO grade II/III gliomas using genome- and transcriptome-wide profiling improves stratification of prognostically distinct patient groups. Acta Neuropathol. 2015, 129, 679-693. [CrossRef] [PubMed]

43. Ceccarelli, M.; Barthel, F.; Malta, T.M.; Sabedot, T.S.; Salama, S.; Murray, B.A.; Morozova, O.; Newton, Y.; Radenbaugh, A.; Pagnotta, S.M.; et al. Molecular Profiling Reveals Biologically Discrete Subsets and Pathways of Progression in Diffuse Glioma. Cell 2016, 164, 550-563. [CrossRef] [PubMed]

44. Cancer Genome Atlas Research Network; Brat, D.J.; Verhaak, R.G.W.; Aldape, K.D.; Yung, W.K.A.; Salama, S.R.; Cooper, L.A.D.; Rheinbay, E.; Miller, C.R.; Vitucci, M.; et al. Comprehensive, Integrative Genomic Analysis of Diffuse Lower-Grade Gliomas. N. Engl. J. Med. 2015, 372, 2481-2498. [CrossRef]

45. Verhaak, R.G.; Hoadley, K.A.; Purdom, E.; Wang, V.; Qi, Y.; Wilkerson, M.D.; Miller, C.R.; Ding, L.; Golub, T.; Mesirov, J.P.; et al. Integrated Genomic Analysis Identifies Clinically Relevant Subtypes of Glioblastoma Characterized by Abnormalities in PDGFRA, IDH1, EGFR, and NF1. Cancer Cell 2010, 17, 98-110. [CrossRef] [PubMed]

46. Babic, I.; Anderson, E.S.; Tanaka, K.; Guo, D.; Masui, K.; Li, B.; Zhu, S.; Gu, Y.; Villa, G.R.; Akhavan, D.; et al. EGFR MutationInduced Alternative Splicing of Max Contributes to Growth of Glycolytic Tumors in Brain Cancer. Cell Metab. 2013, 17, 1000-1008. [CrossRef] [PubMed]

47. Ciriello, G.; Miller, M.L.; Aksoy, B.A.; Senbabaoglu, Y.; Schultz, N.; Sander, C. Emerging landscape of oncogenic signatures across human cancers. Nat. Genet. 2013, 45, 1127-1133. [CrossRef] [PubMed]

48. Tsai, Y.-L.; Chang, H.-H.; Chen, Y.-C.; Chang, Y.-C.; Tsai, Y.C.A.W.-C. Molecular Mechanisms of KDELC2 on Glioblastoma Tumorigenesis and Temozolomide Resistance. Biomedicines 2020, 8, 339. [CrossRef]

49. Karsy, M.; Neil, J.A.; Guan, J.; Mahan, M.A.; Colman, H.; Jensen, R.L. A practical review of prognostic correlations of molecular biomarkers in glioblastoma. Neurosurg. Focus 2015, 38, E4. [CrossRef]

50. Zoncu, R.; Efeyan, A.; Sabatini, D.M. mTOR: From growth signal integration to cancer, diabetes and ageing. Nat. Rev. Mol. Cell Biol. 2010, 12, 21-35. [CrossRef]

51. Seshacharyulu, P.; Ponnusamy, M.P.; Haridas, D.; Jain, M.; Ganti, A.K.; Batra, S.K. Targeting the EGFR signaling pathway in cancer therapy. Expert Opin. Ther. Targets 2012, 16, 15-31. [CrossRef] [PubMed]

52. Vogt, P.K.; Hart, J. PI3K and STAT3: A New Alliance. Cancer Discov. 2011, 1, 481-486. [CrossRef]

53. Paw, I.; Carpenter, R.C.; Watabe, K.; Debinski, W.; Lo, H.-W. Mechanisms regulating glioma invasion. Cancer Lett. 2015, $362,1-7$. [CrossRef]

54. Sami, A.; Karsy, M. Targeting the PI3K/AKT/mTOR signaling pathway in glioblastoma: Novel therapeutic agents and advances in understanding. Tumor Biol. 2013, 34, 1991-2002. [CrossRef]

55. Vanhaesebroeck, B.; Stephens, L.; Hawkins, P.T. PI3K signalling: The path to discovery and understanding. Nat. Rev. Mol. Cell Biol. 2012, 13, 195-203. [CrossRef]

56. Manning, B.D.; Cantley, L.C. AKT/PKB Signaling: Navigating Downstream. Cell 2007, 129, 1261-1274. [CrossRef]

57. Mao, H.; Lebrun, D.G.; Yang, J.; Zhu, V.F.; Li, M. Deregulated Signaling Pathways in Glioblastoma Multiforme: Molecular Mechanisms and Therapeutic Targets. Cancer Investig. 2012, 30, 48-56. [CrossRef] 
58. Nikiforova, M.N.; Hamilton, R.L. Molecular diagnostics of gliomas. Arch. Pathol. Lab. Med. 2011, 135, 558-568. [CrossRef] [PubMed]

59. Masui, K.; Mischel, P.S.; Reifenberger, G. Molecular classification of gliomas. Handb. Clin. Neurol. 2016, 134, 97-120. [CrossRef] [PubMed]

60. Yang, W.; Xia, Y.; Hawke, D.; Li, X.; Liang, J.; Xing, D.; Aldape, K.; Hunter, T.; Yung, W.A.; Lu, Z. PKM2 Phosphorylates Histone H3 and Promotes Gene Transcription and Tumorigenesis. Cell 2012, 150, 685-696. [CrossRef]

61. Phillips, H.S.; Kharbanda, S.; Chen, R.; Forrest, W.F.; Soriano, R.H.; Wu, T.D.; Misra, A.; Nigro, J.M.; Colman, H.; Soroceanu, L.; et al. Molecular subclasses of high-grade glioma predict prognosis, delineate a pattern of disease progression, and resemble stages in neurogenesis. Cancer Cell 2006, 9, 157-173. [CrossRef]

62. Clarke, I.D.; Dirks, P.B. A human brain tumor-derived PDGFR- $\alpha$ deletion mutant is transforming. Oncogene 2003, 22, 722-733. [CrossRef] [PubMed]

63. Smith, J.S.; Wang, X.-Y.; Qian, J.; Hosek, S.M.; Scheithauer, B.W.; Jenkins, R.B.; James, C.D. Amplification of the platelet-derived growth factor receptor-A (PDGFRA) gene occurs in oligodendrogliomas with grade IV anaplastic features. J. Neuropathol. Exp. Neurol. 2000, 59, 495-503. [CrossRef] [PubMed]

64. Lokker, A.N.; Sullivan, C.M.; Hollenbach, S.J.; Israel, A.M.; Giese, A.N. Platelet-derived growth factor (PDGF) autocrine signaling regulates survival and mitogenic pathways in glioblastoma cells: Evidence that the novel PDGF-C and PDGF-D ligands may play a role in the development of brain tumors. Cancer Res. 2002, 62, 3729-3735.

65. Assanah, M.; Lochhead, R.; Ogden, A.; Bruce, J.; Goldman, J.; Canoll, P. Glial Progenitors in Adult White Matter Are Driven to Form Malignant Gliomas by Platelet-Derived Growth Factor-Expressing Retroviruses. J. Neurosci. 2006, 26, 6781-6790. [CrossRef] [PubMed]

66. Loh, K.M.; van Amerongen, R.; Nusse, R. Generating Cellular Diversity and Spatial Form: Wnt Signaling and the Evolution of Multicellular Animals. Dev. Cell 2016, 38, 643-655. [CrossRef]

67. Oren, O.; Smith, B.D. Eliminating Cancer Stem Cells by Targeting Embryonic Signaling Pathways. Stem Cell Rev. Rep. 2017, 13, 17-23. [CrossRef]

68. Al-Harthi, L. Wnt/ $\beta$-catenin and its Diverse Physiological Cell Signaling Pathways in Neurodegenerative and Neuropsychiatric Disorders. J. Neuroimmune Pharmacol. 2012, 7, 725-730. [CrossRef]

69. Marchetti, B.; Pluchino, S. Wnt your brain be inflamed? Yes, it Wnt! Trends Mol. Med. 2013, 19, 144-156. [CrossRef]

70. LeCarpentier, Y.; Claes, V.; Duthoit, G.; Hébert, J.-L. Circadian rhythms, Wnt/beta-catenin pathway and PPAR alpha/gamma profiles in diseases with primary or secondary cardiac dysfunction. Front. Physiol. 2014, 5, 429. [CrossRef]

71. LeCarpentier, Y.; Vallée, A. Opposite Interplay between PPAR Gamma and Canonical Wnt/Beta-Catenin Pathway in Amyotrophic Lateral Sclerosis. Front. Neurol. 2016, 7, 100. [CrossRef]

72. Vallée, A.; LeCarpentier, Y. Alzheimer Disease: Crosstalk between the Canonical Wnt/Beta-Catenin Pathway and PPARs Alpha and Gamma. Front. Neurosci. 2016, 10, 459. [CrossRef]

73. Vallée, A.; LeCarpentier, Y.; Guillevin, R.; Vallée, J.-N. Thermodynamics in Neurodegenerative Diseases: Interplay between Canonical WNT/Beta-Catenin Pathway-PPAR Gamma, Energy Metabolism and Circadian Rhythms. Neuromolecular Med. 2018, 20, 174-204. [CrossRef]

74. Vallée, A.; Vallée, J.-N.; Lecarpentier, Y. Parkinson's Disease: Potential Actions of Lithium by Targeting the WNT/ $\beta$-Catenin Pathway, Oxidative Stress, Inflammation and Glutamatergic Pathway. Cells 2021, 10, 230. [CrossRef] [PubMed]

75. He, T.C.; Sparks, A.B.; Rago, C.; Hermeking, H.; Zawel, L.; da Costa, L.T.; Morin, P.J.; Vogelstein, B.; Kinzler, K.W. Identifi-cation of C-MYC as a Target of the APC Pathway. Science 1998, 281, 1509-1512. [CrossRef] [PubMed]

76. Shtutman, M.; Zhurinsky, J.; Simcha, I.; Albanese, C.; D'Amico, M.; Pestell, R.; Ben-Ze'ev, A. The Cyclin D1 Gene Is a Target of the Beta-Catenin/LEF-1 Pathway. Proc. Natl. Acad. Sci. USA 1999, 96, 5522-5527. [CrossRef] [PubMed]

77. Angers, S.; Moon, R.T. Proximal events in Wnt signal transduction. Nat. Rev. Mol. Cell Biol. 2009, 10, 468-477. [CrossRef]

78. Sharma, C.; Pradeep, A.; Wong, L.; Rana, A.; Rana, B. Peroxisome Proliferator-activated Receptor $\gamma$ Activation Can Regulate $\beta$-Catenin Levels via a Proteasome-mediated and Adenomatous Polyposis Coli-independent Pathway. J. Biol. Chem. 2004, 279, 35583-35594. [CrossRef]

79. Rosi, M.C.; Luccarini, I.; Grossi, C.; Fiorentini, A.; Spillantini, M.G.; Prisco, A.; Scali, C.; Gianfriddo, M.; Caricasole, A.; Terstappen, G.C.; et al. Increased Dickkopf-1 expression in transgenic mouse models of neurodegenerative disease. J. Neurochem. 2010, 112, 1539-1551. [CrossRef] [PubMed]

80. Clevers, H.; Nusse, R. Wnt/ $\beta$-Catenin Signaling and Disease. Cell 2012, 149, 1192-1205. [CrossRef]

81. Inestrosa, N.C.; Montecinos-Oliva, C.; Fuenzalida, M. Wnt Signaling: Role in Alzheimer Disease and Schizophrenia. J. Neuroimmune Pharmacol. 2012, 7, 788-807. [CrossRef]

82. Vallée, A.; LeCarpentier, Y.; Guillevin, R.; Vallée, J.-N. Interactions between TGF- $\beta 1$, canonical WNT/ $\beta$-catenin pathway and PPAR $\gamma$ in radiation-induced fibrosis. Oncotarget 2017, 8, 90579-90604. [CrossRef] [PubMed]

83. Vallée, A.; Lecarpentier, Y.; Vallée, J.-N. Hypothesis of Opposite Interplay between the Canonical WNT/beta-catenin Pathway and PPAR Gamma in Primary Central Nervous System Lymphomas. Curr. Issues Mol. Biol. 2019, 31, 1-20. [CrossRef] [PubMed]

84. Aberle, H.; Bauer, A.; Stappert, J.; Kispert, A.; Kemler, R. $\beta$-catenin is a target for the ubiquitin-proteasome pathway. EMBO J. 1997, 16, 3797-3804. [CrossRef]

85. Wu, D.; Pan, W. GSK3: A Multifaceted Kinase in Wnt Signaling. Trends Biochem. Sci. 2010, 35, 161-168. [CrossRef] 
86. Hur, E.-M.; Zhou, F.-Q. GSK3 signalling in neural development. Nat. Rev. Neurosci. 2010, 11, 539-551. [CrossRef]

87. Ambacher, K.K.; Pitzul, K.B.; Karajgikar, M.; Hamilton, A.; Ferguson, S.S.; Cregan, S.P. The JNK- and AKT/GSK3 $\beta-$ Signaling Pathways Converge to Regulate Puma Induction and Neuronal Apoptosis Induced by Trophic Factor Deprivation. PLoS ONE 2012, 7, e46885. [CrossRef] [PubMed]

88. Orellana, A.M.M.; Vasconcelos, A.R.; Leite, J.A.; Lima, L.D.S.; Andreotti, D.Z.; Munhoz, C.D.; Kawamoto, E.; Scavone, C. Age-related neuroinflammation and changes in AKT-GSK-3 $\beta$ and WNT/ $\beta$-CATENIN signaling in rat hippocampus. Aging 2015, 7, 1094-1108. [CrossRef]

89. Wu, J.-H.; Zhang, S.-H.; Gao, F.-J.; Lei, Y.; Chen, X.-Y.; Zhang, S.-J.; Sun, X.-H. RNAi screening identifies GSK3 $\beta$ as a regulator of DRP1 and the neuroprotection of lithium chloride against elevated pressure involved in downregulation of DRP1. Neurosci. Lett. 2013, 554, 99-104. [CrossRef]

90. Russo, R.; Adornetto, A.; Cavaliere, F.; Varano, G.P.; Rusciano, D.; Morrone, L.A.; Corasaniti, M.T.; Bagetta, G.; Nucci, C. Intravitreal injection of forskolin, homotaurine, and L-carnosine affords neuroprotection to retinal ganglion cells following retinal ischemic injury. Mol. Vis. 2015, 21, 718-729.

91. Vallée, A.; LeCarpentier, Y.; Guillevin, R.; Vallée, J.-N. Thermodynamics in Gliomas: Interactions between the Canonical WNT/Beta-Catenin Pathway and PPAR Gamma. Front. Physiol. 2017, 8, 352. [CrossRef] [PubMed]

92. Vallée, A.; LeCarpentier, Y.; Guillevin, R.; Vallée, J.-N. Opposite Interplay Between the Canonical WNT/ $\beta$-Catenin Pathway and PPAR Gamma: A Potential Therapeutic Target in Gliomas. Neurosci. Bull. 2018, 34, 573-588. [CrossRef] [PubMed]

93. Vallée, A.; LeCarpentier, Y.; Vallée, J.-N. Targeting the Canonical WNT/ $\beta$-Catenin Pathway in Cancer Treatment Using NonSteroidal Anti-Inflammatory Drugs. Cells 2019, 8, 726. [CrossRef] [PubMed]

94. Vallée, A.; Vallée, J.-N.; LeCarpentier, Y. PPAR $\gamma$ agonists: Potential treatment for autism spectrum disorder by inhibiting the canonical WNT/ $\beta$-catenin pathway. Mol. Psychiatry 2019, 24, 643-652. [CrossRef] [PubMed]

95. Vallée, A.; Lecarpentier, Y.; Guillevin, R.; Vallée, J.-N. The influence of circadian rhythms and aerobic glycolysis in autism spectrum disorder. Transl. Psychiatry 2020, 10, 400. [CrossRef]

96. Vallée, A.; Vallée, J.-N.; Guillevin, R.; Lecarpentier, Y. Riluzole: A therapeutic strategy in Alzheimer's disease by targeting the WNT/ $\beta$-catenin pathway. Aging 2020, 12, 3095-3113. [CrossRef] [PubMed]

97. Vallée, A.; Vallée, J.-N. Warburg effect hypothesis in autism Spectrum disorders. Mol. Brain 2018, 11, 1. [CrossRef]

98. Sareddy, G.R.; Panigrahi, M.; Challa, S.; Mahadevan, A.; Babu, P.P. Activation of Wnt/ $\beta$-catenin/Tcf signaling pathway in human astrocytomas. Neurochem. Int. 2009, 55, 307-317. [CrossRef]

99. Utsuki, S.; Sato, Y.; Oka, H.; Tsuchiya, B.; Suzuki, S.; Fujii, K. Relationship between the Expression of E-, N-cadherins and beta-catenin and Tumor Grade in Astrocytomas. J. Neuro-Oncol. 2002, 57, 187-192. [CrossRef]

100. Zhang, Z.-Q.; Chen, H.-Q.; Chen, Y.-H.; Cheng, X.-F. [Significance of beta-catenin and Cyclin D1 express in glioma]. Chin. J. Cell. Mol. Immunol. 2009, 25, 1010-1012.

101. Denysenko, T.; Annovazzi, L.; Cassoni, P.; Melcarne, A.; Mellai, M.; Schiffer, D. WNT/ $\beta$-catenin Signaling Pathway and Downstream Modulators in Low- and High-grade Glioma. Cancer Genom. Proteom. 2015, 13, 31-45.

102. Liu, X.; Wang, L.; Zhao, S.; Ji, X.; Luo, Y.; Ling, F. $\beta$-Catenin overexpression in malignant glioma and its role in proliferation and apoptosis in glioblastma cells. Med. Oncol. 2010, 28, 608-614. [CrossRef]

103. Liu, C.; Tu, Y.; Sun, X.; Jiang, J.; Jin, X.; Bo, X.; Li, Z.; Bian, A.; Wang, X.; Liu, D.; et al. Wnt/beta-Catenin pathway in human glioma: Expression pattern and clinical/prognostic correlations. Clin. Exp. Med. 2010, 11, 105-112. [CrossRef] [PubMed]

104. Yang, Z.; Wang, Y.; Fang, J.; Chen, F.; Liu, J.; Wu, J.; Wang, Y.; Song, T.; Zeng, F.; Rao, Y. Downregulation of WIF-1 by Hy-permethylation in Astrocytomas. Acta Biochim. Biophys. Sin. 2010, 42, 418-425. [CrossRef] [PubMed]

105. Yang, C.; Iyer, R.R.; Yu, A.C.H.; Yong, R.L.; Park, D.M.; Weil, R.J.; Ikejiri, B.; Brady, R.O.; Lonser, R.R.; Zhuang, Z. -Catenin signaling initiates the activation of astrocytes and its dysregulation contributes to the pathogenesis of astrocytomas. Proc. Natl. Acad. Sci. USA 2012, 109, 6963-6968. [CrossRef]

106. Sareddy, G.R.; Pratap, U.P.; Viswanadhapalli, S.; Venkata, P.P.; Nair, B.C.; Krishnan, S.R.; Zheng, S.; Gilbert, A.R.; Brenner, A.J.; Brann, D.W.; et al. PELP1 promotes glioblastoma progression by enhancing Wnt/ $\beta$-catenin signaling. Neuro-Oncol. Adv. 2019, 1. [CrossRef]

107. Portela, M.; Casas-Tintó, S. New Cellular Dimensions on Glioblastoma Progression. Neurosci. Insights 2020, 15, 2633105520923076. [CrossRef]

108. Xu, A.; Yang, H.; Gao, K.; Zhan, Z.; Song, Z.; Huang, T.; Song, Y. Expression profiles and prognostic significance of WNT family members in glioma via bioinformatic analysis. Biosci. Rep. 2020, 40. [CrossRef] [PubMed]

109. Huo, X.-Y.; Zhang, X.-Y.; Yuan, F.; Zhao, X.-Y.; You, B.-A. HOXB7 Promotes Proliferation and Metastasis of Glioma by Reg-ulating the Wnt/ $\beta$-Catenin Pathway. Eur. Rev. Med. Pharmacol. Sci. 2021, 25, 3146. [CrossRef] [PubMed]

110. Sun, J.; Ma, Q.; Shu, C.; Xiong, J.; Li, B.; Wu, J.; Zhang, S.; Li, J.; Liu, J.; Wang, J. MicroRNA-301a/ZNRF3/wnt/ $\beta$-catenin signal regulatory crosstalk mediates glioma progression. Int. J. Oncol. 2020, 58, 45-56. [CrossRef]

111. Shou, J.; Ali-Osman, F.; Multani, A.S.; Pathak, S.; Fedi, P.; Srivenugopal, K.S. Human Dkk-1, a gene encoding a Wnt antagonist, responds to DNA damage and its overexpression sensitizes brain tumor cells to apoptosis following alkylation damage of DNA. Oncogene 2002, 21, 878-889. [CrossRef]

112. Roth, W.; Wild-Bode, C.; Platten, M.; Grimmel, C.; Melkonyan, H.S.; Dichgans, J.; Weller, M. Secreted Frizzled-related proteins inhibit motility and promote growth of human malignant glioma cells. Oncogene 2000, 19, 4210-4220. [CrossRef] 
113. Delic, S.; Lottmann, N.; Stelzl, A.; Liesenberg, F.; Wolter, M.; Götze, S.; Zapatka, M.; Shiio, Y.; Sabel, M.C.; Felsberg, J.; et al. MiR-328 promotes glioma cell invasion via SFRP1-dependent Wnt-signaling activation. Neuro-Oncology 2013, 16, 179-190. [CrossRef]

114. Jin, X.; Jeon, H.-Y.; Joo, K.M.; Kim, J.-K.; Jin, J.; Kim, S.H.; Kang, B.G.; Beck, S.; Lee, S.J.; Kim, J.K.; et al. Frizzled 4 Regulates Stemness and Invasiveness of Migrating Glioma Cells Established by Serial Intracranial Transplantation. Cancer Res. 2011, 71, 3066-3075. [CrossRef]

115. Huang, P.H.; Xu, A.M.; White, F.M. Oncogenic EGFR Signaling Networks in Glioma. Sci. Signal. 2009, 2, re6. [CrossRef] [PubMed]

116. Karpel-Massler, G.; Schmidt, U.; Unterberg, A.; Halatsch, M.-E. Therapeutic Inhibition of the Epidermal Growth Factor Receptor in High-Grade Gliomas: Where Do We Stand? Mol. Cancer Res. 2009, 7, 1000-1012. [CrossRef] [PubMed]

117. Kang, C.; Chen, L.; Huang, K.; Han, L.; Shi, Z.; Zhang, K.; Pu, P.; Jiang, C.; Kang, C. $\beta$-Catenin/Tcf-4 Complex transcriptionally regulates AKT1 in glioma. Int. J. Oncol. 2011, 39, 883-890. [CrossRef]

118. Kong, D.-S.; Song, S.-Y.; Kim, D.-H.; Joo, K.M.; Yoo, J.-S.; Koh, J.S.; Dong, S.M.; Suh, Y.-L.; Lee, J.-I.; Park, K.; et al. Prognostic significance of c-Met expression in glioblastomas. Cancer 2008, 115, 140-148. [CrossRef] [PubMed]

119. Nabeshima, K.; Shimao, Y.; Sato, S.; Kataoka, H.; Moriyama, T.; Kawano, H.; Wakisaka, S.; Koono, M. Expression of c-Met correlates with grade of malignancy in human astrocytic tumours: An immunohistochemical study. Histopathology 1997, 31, 436-443. [CrossRef] [PubMed]

120. Louis, D.N. Molecular pathology of malignant gliomas. Annu. Rev. Pathol. Mech. Dis. 2006, 1, 97-117. [CrossRef]

121. Mizoguchi, M.; Betensky, R.A.; Batchelor, T.T.; Bernay, D.C.; Louis, D.N.; Nutt, C.L. Activation of STAT3, MAPK, and AKT in malignant astrocytic gliomas: Correlation with EGFR status, tumor grade, and survival. J. Neuropathol. Exp. Neurol. 2006, 65, 1181-1188. [CrossRef]

122. Organ, S.L.; Tsao, M.-S. An overview of the c-MET signaling pathway. Ther. Adv. Med. Oncol. 2011, 3, S7-S19. [CrossRef]

123. Kessler, J.; Güttler, A.; Wichmann, H.; Rot, S.; Kappler, M.; Bache, M.; Vordermark, D. IDH1R132H mutation causes a less aggressive phenotype and radiosensitizes human malignant glioma cells independent of the oxygenation status. Radiother. Oncol. 2015, 116, 381-387. [CrossRef]

124. Anson, M.; Crain-Denoyelle, A.-M.; Baud, V.; Chereau, F.; Gougelet, A.; Terris, B.; Yamagoe, S.; Colnot, S.; Viguier, M.; Perret, C.; et al. Oncogenic $\beta$-catenin triggers an inflammatory response that determines the aggressiveness of hepatocellular carcinoma in mice. J. Clin. Investig. 2012, 122, 586-599. [CrossRef] [PubMed]

125. Valenta, T.; Hausmann, G.; Basler, K. The many faces and functions of $\beta$-catenin. EMBO J. 2012, 31, 2714-2736. [CrossRef]

126. Cui, D.; Ren, J.; Shi, J.; Feng, L.; Wang, K.; Zeng, T.; Jin, Y.; Gao, L. R132H mutation in IDH1 gene reduces proliferation, cell survival and invasion of human glioma by downregulating Wnt/ $\beta$-catenin signaling. Int. J. Biochem. Cell Biol. 2016, $73,72-81$. [CrossRef]

127. Shi, J.; Sun, B.; Shi, W.; Zuo, H.; Cui, D.; Ni, L.; Chen, J. Decreasing GSH and increasing ROS in chemosensitivity gliomas with IDH1 mutation. Tumor Biol. 2014, 36, 655-662. [CrossRef] [PubMed]

128. Shi, J.; Zuo, H.; Ni, L.; Xia, L.; Zhao, L.; Gong, M.; Nie, D.; Gong, P.; Cui, D.; Shi, W.; et al. An IDH1 mutation inhibits growth of glioma cells via GSH depletion and ROS generation. Neurol. Sci. 2013, 35, 839-845. [CrossRef] [PubMed]

129. Vallée, A.; Guillevin, R.; Vallée, J.-N. Vasculogenesis and angiogenesis initiation under normoxic conditions through Wnt/ $\beta$ catenin pathway in gliomas. Rev. Neurosci. 2017, 29, 71-91. [CrossRef] [PubMed]

130. Koul, D. PTEN Signaling pathways in glioblastoma. Cancer Biol. Ther. 2008, 7, 1321-1325. [CrossRef]

131. Birner, P.; Pusch, S.; Christov, C.; Mihaylova, S.; Ms, K.T.; Natchev, S.; Schoppmann, S.F.; Tchorbanov, A.; Streubel, B.; Tuettenberg, J.; et al. Mutant IDH1 inhibits PI3K/Akt signaling in human glioma. Cancer 2014, 120, 2440-2447. [CrossRef] [PubMed]

132. Bleau, A.-M.; Hambardzumyan, D.; Ozawa, T.; Fomchenko, E.I.; Huse, J.T.; Brennan, C.W.; Holland, E.C. PTEN/PI3K/Akt Pathway Regulates the Side Population Phenotype and ABCG2 Activity in Glioma Tumor Stem-like Cells. Cell Stem Cell 2009, 4, 226-235. [CrossRef] [PubMed]

133. Huse, J.T.; Brennan, C.; Hambardzumyan, D.; Wee, B.; Pena, J.; Rouhanifard, S.H.; Sohn-Lee, C.; Le Sage, C.; Agami, R.; Tuschl, T.; et al. The PTEN-regulating microRNA miR-26a is amplified in high-grade glioma and facilitates gliomagenesis in vivo. Genes Dev. 2009, 23, 1327-1337. [CrossRef]

134. Yao, Q.; Cai, G.; Yu, Q.; Shen, J.; Gu, Z.; Chen, J.; Shi, W.; Shi, J. IDH1 mutation diminishes aggressive phenotype in glioma stem cells. Int. J. Oncol. 2017, 52, 270-278. [CrossRef]

135. Mehrjardi, N.Z.; Hänggi, D.; Kahlert, U.D. Current biomarker-associated procedures of cancer modeling-a reference in the context of IDH1 mutant glioma. Cell Death Dis. 2020, 11, 1-12. [CrossRef] [PubMed]

136. Bleeker, F.E.; Atai, N.A.; Lamba, S.; Jonker, A.; Rijkeboer, D.; Bosch, K.S.; Tigchelaar, W.; Troost, D.; Vandertop, W.P.; Bardelli, A.; et al. The prognostic IDH1 R132 mutation is associated with reduced NADP+-dependent IDH activity in glioblastoma. Acta Neuropathol. 2010, 119, 487-494. [CrossRef]

137. Metellus, P.; Colin, C.; Taieb, D.; Guedj, E.; Nanni-Metellus, I.; De Paula, A.M.; Colavolpe, C.; Fuentes, S.; Dufour, H.; Barrie, M.; et al. IDH mutation status impact on in vivo hypoxia biomarkers expression: New insights from a clinical, nuclear imaging and immunohistochemical study in 33 glioma patients. J. Neuro-Oncol. 2011, 105, 591-600. [CrossRef]

138. Williams, S.C.; Karajannis, M.A.; Chiriboga, L.; Golfinos, J.G.; Von Deimling, A.; Zagzag, D. R132H-mutation of isocitrate dehydrogenase-1 is not sufficient for HIF-1 $\alpha$ upregulation in adult glioma. Acta Neuropathol. 2011, 121, 279-281. [CrossRef] 
139. Tchoghandjian, A.; Koh, M.Y.; Taieb, D.; Ganaha, S.; Powis, G.; Bialecki, E.; Graziani, N.; Figarella-Branger, D.; Metellus, P. Hypoxia-associated factor expression in low-grade and anaplastic gliomas: A marker of poor outcome. Oncotarget 2014, 5. [CrossRef]

140. Zhang, Z.; Leonard, S.S.; Huang, C.; Vallyathan, V.; Castranova, V.; Shi, X. Role of reactive oxygen species and MAPKs in vanadate-induced G2/M phase arrest. Free Radic. Biol. Med. 2003, 34, 1333-1342. [CrossRef]

141. Menon, S.G.; Goswami, P.C. A redox cycle within the cell cycle: Ring in the old with the new. Oncogene 2006, 26, 1101-1109. [CrossRef]

142. Sharma, V.; Joseph, C.; Ghosh, S.; Agarwal, A.; Mishra, M.K.; Sen, E. Kaempferol induces apoptosis in glioblastoma cells through oxidative stress. Mol. Cancer Ther. 2007, 6, 2544-2553. [CrossRef]

143. Deng, S.; Yang, Y.; Han, Y.; Li, X.; Wang, X.; Li, X.; Zhang, Z.; Wang, Y. UCP2 Inhibits ROS-Mediated Apoptosis in A549 under Hypoxic Conditions. PLoS ONE 2012, 7, e30714. [CrossRef] [PubMed]

144. Guha, P.; Dey, A.; Sen, R.; Chatterjee, M.; Chattopadhyay, S.; Bandyopadhyay, S.K. Intracellular GSH Depletion Triggered Mitochondrial Bax Translocation to Accomplish Resveratrol-Induced Apoptosis in the U937 Cell Line. J. Pharmacol. Exp. Ther. 2010, 336, 206-214. [CrossRef] [PubMed]

145. Gottesman, M.M.; Fojo, T.; Bates, S.E. Multidrug resistance in cancer: Role of ATP-dependent transporters. Nat. Rev. Cancer 2002, 2, 48-58. [CrossRef] [PubMed]

146. Izawa, S.; Maeda, K.; Miki, T.; Mano, J.; Inoue, Y.; Kimura, A. Importance of glucose-6-phosphate dehydrogenase in the adaptive response to hydrogen peroxide in Saccharomyces cerevisiae. Biochem. J. 1998, 330, 811-817. [CrossRef]

147. Gillies, R.J.; Gatenby, R.A. Metabolism and Its Sequelae in Cancer Evolution and Therapy. Cancer J. 2015, 21, 88-96. [CrossRef]

148. Gillies, R.J.; Gatenby, R.A. Adaptive landscapes and emergent phenotypes: Why do cancers have high glycolysis? J. Bioenerg. Biomembr. 2007, 39, 251-257. [CrossRef] [PubMed]

149. Semenza, G.L. HIF-1: Upstream and downstream of cancer metabolism. Curr. Opin. Genet. Dev. 2010, 20, 51-56. [CrossRef]

150. Semenza, G.L. Oxygen Sensing, Homeostasis, and Disease. N. Engl. J. Med. 2011, 365, 537-547. [CrossRef]

151. Samanta, D.; Semenza, G.L. Metabolic adaptation of cancer and immune cells mediated by hypoxia-inducible factors. Biochim. Biophys. Acta Rev. Cancer. 2018, 1870, 15-22. [CrossRef] [PubMed]

152. Wu, G.; Luo, J.; Rana, J.S.; Laham, R.; Sellke, F.W.; Li, J. Involvement of COX-2 in VEGF-induced angiogenesis via P38 and JNK pathways in vascular endothelial cells. Cardiovasc. Res. 2006, 69, 512-519. [CrossRef] [PubMed]

153. Airley, R.E.; Mobasheri, A. Hypoxic Regulation of Glucose Transport, Anaerobic Metabolism and Angiogenesis in Cancer: Novel Pathways and Targets for Anticancer Therapeutics. Chemotherapy 2007, 53, 233-256. [CrossRef] [PubMed]

154. Liang, C.; Guo, S.; Yang, L. All-trans retinoic acid upregulates VEGF expression in glioma cells in vitro. J. Biomed. Res. 2013, 27, 51-55. [CrossRef] [PubMed]

155. Zhao, S.; Lin, Y.; Xu, W.; Jiang, W.; Zha, Z.; Wang, P.; Yu, W.; Li, Z.; Gong, L.; Peng, Y.; et al. Glioma-Derived Mutations in IDH1 Dominantly Inhibit IDH1 Catalytic Activity and Induce HIF-1. Science 2009, 324, 261-265. [CrossRef]

156. Xu, W.; Yang, H.; Liu, Y.; Yang, Y.; Wang, P.; Kim, S.-H.; Ito, S.; Yang, C.; Wang, P.; Xiao, M.-T.; et al. Oncometabolite 2Hydroxyglutarate Is a Competitive Inhibitor of $\alpha$-Ketoglutarate-Dependent Dioxygenases. Cancer Cell 2011, 19, 17-30. [CrossRef]

157. Jha, M.K.; Suk, K. Pyruvate Dehydrogenase Kinase as a Potential Therapeutic Target for Malignant Gliomas. Brain Tumor Res. Treat. 2013, 1, 57-63. [CrossRef]

158. Warburg, O. On the Origin of Cancer Cells. Science 1956, 123, 309-314. [CrossRef]

159. Maxwell, P. Activation of the HIF pathway in cancer. Curr. Opin. Genet. Dev. 2001, 11, 293-299. [CrossRef]

160. Hanahan, D.; Weinberg, R.A. Hallmarks of Cancer: The Next Generation. Cell 2011, 144, 646-674. [CrossRef] [PubMed]

161. Cubuk, C.; Hidalgo, M.R.; Amadoz, A.; Pujana, M.A.; Mateo, F.; Herranz, C.; Carbonell-Caballero, J.; Dopazo, J. Gene Expression Integration into Pathway Modules Reveals a Pan-Cancer Metabolic Landscape. Cancer Res. 2018, 78, 6059-6072. [CrossRef]

162. Çubuk, C.; Hidalgo, M.R.; Amadoz, A.; Rian, K.; Salavert, F.; Pujana, M.A.; Mateo, F.; Herranz, C.; Carbonell-Caballero, J.; Dopazo, J. Differential metabolic activity and discovery of therapeutic targets using summarized metabolic pathway models. NPJ Syst. Biol. Appl. 2019, 5, 7. [CrossRef] [PubMed]

163. Seyfried, T.N.; Mukherjee, P. Targeting energy metabolism in brain cancer: Review and hypothesis. Nutr. Metab. 2005, 2, 30. [CrossRef]

164. Ristow, M. Oxidative metabolism in cancer growth. Curr. Opin. Clin. Nutr. Metab. Care 2006, 9, 339-345. [CrossRef] [PubMed]

165. Maurer, G.D.; Brucker, D.P.; Bähr, O.; Harter, P.N.; Hattingen, E.; Walenta, S.; Mueller-Klieser, W.; Steinbach, J.P.; Rieger, J. Differential utilization of ketone bodies by neurons and glioma cell lines: A rationale for ketogenic diet as experimental glioma therapy. BMC Cancer 2011, 11, 315. [CrossRef] [PubMed]

166. Mineura, K.; Yasuda, T.; Kowada, M.; Shishido, F.; Ogawa, T.; Uemura, K. Positron emission tomographic evaluation of histological malignancy in gliomas using oxygen-15 and fluorine-18-fluorodeoxyglucose. Neurol. Res. 1986, 8, 164-168. [CrossRef]

167. Oudard, S.; Arvelo, F.; Miccoli, L.; Apiou, F.; Dutrillaux, A.M.; Poisson, M.; Dutrillaux, B.; Poupon, M.F. High glycolysis in gliomas despite low hexokinase transcription and activity correlated to chromosome 10 loss. Br. J. Cancer 1996, 74, 839-845. [CrossRef]

168. Constant, J.S.; Feng, J.J.; Zabel, D.D.; Yuan, H.; Suh, D.Y.; Scheuenstuhl, H.; Hunt, T.K.; Hussain, M.Z. Lactate elicits vascular endothelial growth factor from macrophages: A possible alternative to hypoxia. Wound Repair Regen. 2000, 8, 353-360. [CrossRef]

169. Thompson, C.B. Wnt meets Warburg: Another piece in the puzzle? EMBO J. 2014, 33, 1420-1422. [CrossRef] 
170. Wise, D.R.; DeBerardinis, R.J.; Mancuso, A.; Sayed, N.; Zhang, X.-Y.; Pfeiffer, H.K.; Nissim, I.; Daikhin, E.; Yudkoff, M.; McMahon, S.B.; et al. Myc regulates a transcriptional program that stimulates mitochondrial glutaminolysis and leads to glutamine addiction. Proc. Natl. Acad. Sci. USA 2008, 105, 18782-18787. [CrossRef]

171. Kim, J.-W.; Gao, P.; Liu, Y.-C.; Semenza, G.L.; Dang, C.V. Hypoxia-Inducible Factor 1 and Dysregulated c-Myc Cooperatively Induce Vascular Endothelial Growth Factor and Metabolic Switches Hexokinase 2 and Pyruvate Dehydrogenase Kinase 1. Mol. Cell. Biol. 2007, 27, 7381-7393. [CrossRef]

172. Lum, J.J.; Bui, T.; Gruber, M.; Gordan, J.D.; DeBerardinis, R.J.; Covello, K.L.; Simon, M.C.; Thompson, C.B. The transcription factor HIF-1 plays a critical role in the growth factor-dependent regulation of both aerobic and anaerobic glycolysis. Genes Dev. 2007, 21, 1037-1049. [CrossRef] [PubMed]

173. Brabletz, T.; Hlubek, F.; Spaderna, S.; Schmalhofer, O.; Hiendlmeyer, E.; Jung, A.; Kirchner, T. Invasion and Metastasis in Colorectal Cancer: Epithelial-Mesenchymal Transition, Mesenchymal-Epithelial Transition, Stem Cells and $\beta$-Catenin. Cells Tissues Organs 2005, 179, 56-65. [CrossRef] [PubMed]

174. Pate, K.T.; Stringari, C.; Sprowl-Tanio, S.; Wang, K.; TeSlaa, T.; Hoverter, N.P.; McQuade, M.; Garner, C.; Digman, A.M.; Teitell, A.M.; et al. Wnt signaling directs a metabolic program of glycolysis and angiogenesis in colon cancer. EMBO J. 2014, 33, 1454-1473. [CrossRef] [PubMed]

175. Chafey, P.; Finzi, L.; Boisgard, R.; Caüzac, M.; Clary, G.; Broussard, C.; Pégorier, J.-P.; Guillonneau, F.; Mayeux, P.; Camoin, L.; et al. Proteomic analysis of $\beta$-catenin activation in mouse liver by DIGE analysis identifies glucose metabolism as a new target of the Wnt pathway. Proteomics 2009, 9, 3889-3900. [CrossRef] [PubMed]

176. Dang, C.V. Rethinking the Warburg Effect with Myc Micromanaging Glutamine Metabolism. Cancer Res. 2010, 70, 859-862. [CrossRef]

177. Moon, R.T. The Promise and Perils of Wnt Signaling Through Beta-Catenin. Science 2002, 296, 1644-1646. [CrossRef] [PubMed]

178. Niehrs, C.; Acebron, S.P. Mitotic and mitogenic Wnt signalling. EMBO J. 2012, 31, 2705-2713. [CrossRef]

179. van de Wetering, M.; Sancho, E.; Verweij, C.; de Lau, W.; Oving, I.; Hurlstone, A.; van der Horn, K.; Batlle, E.; Coudreuse, D.; Haramis, A.P.; et al. The Beta-Catenin/TCF-4 Complex Imposes a Crypt Progenitor Phenotype on Colorectal Cancer Cells. Cell 2002, 111, 241-250. [CrossRef]

180. Popescu, A.M.; Purcaru, S.O.; Alexandru, O.; Dricu, A. New perspectives in glioblastoma antiangiogenic therapy. Wspótczesna Onkol. 2016, 20, 109-118. [CrossRef]

181. Park, K.S.; Da Lee, R.; Kang, S.-K.; Han, S.Y.; Park, K.L.; Yang, K.H.; Song, Y.S.; Park, H.J.; Lee, Y.M.; Yun, Y.P.; et al. Neuronal differentiation of embryonic midbrain cells by upregulation of peroxisome proliferator-activated receptor-gamma via the JNK-dependent pathway. Exp. Cell Res. 2004, 297, 424-433. [CrossRef] [PubMed]

182. Tan, X.; Apte, U.; Micsenyi, A.; Kotsagrelos, E.; Luo, J.-H.; Ranganathan, S.; Monga, D.K.; Bell, A.; Michalopoulos, G.K.; Monga, S.P.S. Epidermal Growth Factor Receptor: A Novel Target of the Wnt/Beta-Catenin Pathway in Liver. Gastroenterology 2005, 129, 285-302. [CrossRef] [PubMed]

183. Yue, X.; Lan, F.; Yang, W.; Yang, Y.; Han, L.; Zhang, A.; Liu, J.; Zeng, H.; Jiang, T.; Pu, P.; et al. Interruption of $\beta$-catenin suppresses the EGFR pathway by blocking multiple oncogenic targets in human glioma cells. Brain Res. 2010, 1366, 27-37. [CrossRef]

184. Zhang, J.; Huang, K.; Shi, Z.; Zou, J.; Wang, Y.; Jia, Z.; Zhang, A.; Han, L.; Yue, X.; Liu, N.; et al. High -catenin/Tcf-4 activity confers glioma progression via direct regulation of AKT2 gene expression. Neuro-Oncology 2011, 13, 600-609. [CrossRef]

185. Elstrom, R.L.; Bauer, D.E.; Buzzai, M.; Karnauskas, R.; Harris, M.H.; Plas, D.R.; Zhuang, H.; Cinalli, R.M.; Alavi, A.; Rudin, C.M.; et al. Akt Stimulates Aerobic Glycolysis in Cancer Cells. Cancer Res. 2004, 64, 3892-3899. [CrossRef]

186. Hunt, T.K.; Aslam, R.S.; Beckert, S.; Wagner, S.; Ghani, Q.P.; Hussain, M.Z.; Roy, S.; Sen, C.K. Aerobically Derived Lactate Stimulates Revascularization and Tissue Repair via Redox Mechanisms. Antioxid. Redox Signal. 2007, 9, 1115-1124. [CrossRef]

187. Ward, P.; Thompson, C.B. Metabolic Reprogramming: A Cancer Hallmark Even Warburg Did Not Anticipate. Cancer Cell 2012, 21, 297-308. [CrossRef]

188. Reuter, S.; Gupta, S.C.; Chaturvedi, M.M.; Aggarwal, B.B. Oxidative stress, inflammation, and cancer: How are they linked? Free Radic. Biol. Med. 2010, 49, 1603-1616. [CrossRef]

189. Sun, Q.; Chen, X.; Ma, J.; Peng, H.; Wang, F.; Zha, X.; Wang, Y.; Jing, Y.; Yang, H.; Chen, R.; et al. Mammalian target of rapamycin up-regulation of pyruvate kinase isoenzyme type M2 is critical for aerobic glycolysis and tumor growth. Proc. Natl. Acad. Sci. USA 2011, 108, 4129-4134. [CrossRef]

190. Jung, J.E.; Lee, H.; Cho, I.; Chung, D.H.; Yoon, S.; Yang, Y.M.; Lee, J.W.; Choi, S.; Park, J.; Ye, S.; et al. STAT3 is a potential modulator of HIF-1-mediated VEGF expression in human renal carcinoma cells. FASEB J. 2005, 19, 1296-1298. [CrossRef]

191. Yan, S.; Zhou, C.; Zhang, W.; Zhang, G.; Zhao, X.; Yang, S.; Wang, Y.; Lu, N.; Zhu, H.; Xu, N. $\beta$-Catenin/TCF pathway upregulates STAT3 expression in human esophageal squamous cell carcinoma. Cancer Lett. 2008, 271, 85-97. [CrossRef]

192. Sinibaldi, D.; Wharton, W.; Turkson, J.; Bowman, T.; Pledger, W.J.; Jove, R. Induction of p21WAF1/CIP1 and cyclin D1 expression by the Src oncoprotein in mouse fibroblasts: Role of activated STAT3 signaling. Oncogene 2000, 19, 5419-5427. [CrossRef] [PubMed]

193. Dekanty, A.; Lavista-Llanos, S.; Irisarri, M.; Oldham, S.; Wappner, P. The insulin-PI3K/TOR pathway induces a HIF-dependent transcriptional response in Drosophila by promoting nuclear localization of HIF- $\alpha /$ Sima. J. Cell Sci. 2005, 118, 5431-5441. [CrossRef] 
194. Milovanova, T.N.; Bhopale, V.M.; Sorokina, E.M.; Moore, J.S.; Hunt, T.K.; Hauer-Jensen, M.; Velazquez, O.C.; Thom, S.R. Lactate Stimulates Vasculogenic Stem Cells via the Thioredoxin System and Engages an Autocrine Activation Loop Involving Hypoxia-Inducible Factor 1. Mol. Cell. Biol. 2008, 28, 6248-6261. [CrossRef]

195. Shaw, R.J. Glucose metabolism and cancer. Curr. Opin. Cell Biol. 2006, 18, 598-608. [CrossRef]

196. Brugarolas, J.B.; Vazquez, F.; Reddy, A.; Sellers, W.R.; Kaelin, W.G. TSC2 Regulates VEGF through MTOR-Dependent and -Independent Pathways. Cancer Cell 2003, 4, 147-158. [CrossRef]

197. Düvel, K.; Yecies, J.L.; Menon, S.; Raman, P.; Lipovsky, A.I.; Souza, A.L.; Triantafellow, E.; Ma, Q.; Gorski, R.; Cleaver, S.; et al. Activation of a Metabolic Gene Regulatory Network Downstream of mTOR Complex 1. Mol. Cell 2010, 39, 171-183. [CrossRef]

198. Land, S.C.; Tee, A.R. Hypoxia-inducible Factor $1 \alpha$ Is Regulated by the Mammalian Target of Rapamycin (mTOR) via an mTOR Signaling Motif. J. Biol. Chem. 2007, 282, 20534-20543. [CrossRef]

199. Toschi, A.; Lee, E.; Gadir, N.; Ohh, M.; Foster, D.A. Differential Dependence of Hypoxia-inducible Factors $1 \alpha$ and $2 \alpha$ on mTORC1 and mTORC2. J. Biol. Chem. 2008, 283, 34495-34499. [CrossRef] [PubMed]

200. Xu, Q.; Briggs, J.; Park, S.; Niu, G.; Kortylewski, M.; Zhang, S.; Gritsko, T.; Turkson, J.; Kay, H.; Semenza, G.L.; et al. Targeting Stat 3 blocks both HIF-1 and VEGF expression induced by multiple oncogenic growth signaling pathways. Oncogene 2005, 24, 5552-5560. [CrossRef] [PubMed]

201. Dibble, C.C.; Cantley, L.C. Regulation of mTORC1 by PI3K signaling. Trends Cell Biol. 2015, 25, 545-555. [CrossRef]

202. Gan, X.; Wang, J.; Su, B.; Wu, D. Evidence for Direct Activation of mTORC2 Kinase Activity by Phosphatidylinositol 3,4,5Trisphosphate. J. Biol. Chem. 2011, 286, 10998-11002. [CrossRef]

203. Kaur, B.; Tan, C.; Brat, D.J.; Van Meir, E.G. Genetic and hypoxic regulation of angiogenesis in gliomas. J. Neuro-Oncology 2004, 70, 229-243. [CrossRef] [PubMed]

204. Ohgaki, H.; Dessen, P.; Jourde, B.; Horstmann, S.; Nishikawa, T.; Di Patre, P.-L.; Burkhard, C.; Schüler, D.; Probst-Hensch, N.M.; Maiorka, P.C.; et al. Genetic Pathways to Glioblastoma. Cancer Res. 2004, 64, 6892-6899. [CrossRef] [PubMed]

205. Parliament, M.B.; Allalunis-Turner, M.J.; Franko, A.J.; Olive, P.L.; Mandyam, R.; Santos, C.; Wolokoff, B. Vascular endothelial growth factor expression is independent of hypoxia in human malignant glioma spheroids and tumours. Br. J. Cancer 2000, 82, 635-641. [CrossRef] [PubMed]

206. Semenza, G.L. Defining the role of hypoxia-inducible factor 1 in cancer biology and therapeutics. Oncogene 2009, 29, 625-634. [CrossRef]

207. Zagzag, D.; Zhong, H.; Scalzitti, J.M.; Laughner, E.; Simons, J.W.; Semenza, G.L. Expression of hypoxia-inducible factor 1alpha in brain tumors: Association with angiogenesis, invasion, and progression. Cancer 2000, 88, 2606-2618. [CrossRef]

208. Semenza, G.L. Targeting HIF-1 for cancer therapy. Nat. Rev. Cancer 2003, 3, 721-732. [CrossRef] [PubMed]

209. Brahimi-Horn, M.C.; Chiche, J.; Pouysségur, J. Hypoxia and cancer. J. Mol. Med. 2007, 85, 1301-1307. [CrossRef]

210. Unruh, A.; Ressel, A.; Mohamed, H.G.; Johnson, R.S.; Nadrowitz, R.; Richter, E.; Katschinski, D.M.; Wenger, R.H. The hypoxiainducible factor- $1 \alpha$ is a negative factor for tumor therapy. Oncogene 2003, 22, 3213-3220. [CrossRef] [PubMed]

211. Valvona, C.J.; Fillmore, H.L.; Nunn, P.B.; Pilkington, G.J. The Regulation and Function of Lactate Dehydrogenase A: Therapeutic Potential in Brain Tumor. Brain Pathol. 2015, 26, 3-17. [CrossRef] [PubMed]

212. Gohil, K.; Brooks, G.A. Exercise tames the wild side of the Myc network: A hypothesis. Am. J. Physiol. Metab. 2012, 303, E18-E30. [CrossRef]

213. Giatromanolaki, A.; Sivridis, E.; Gatter, K.C.; Turley, H.; Harris, A.L.; Koukourakis, M.I. Lactate dehydrogenase 5 (LDH-5) expression in endometrial cancer relates to the activated VEGF/VEGFR2(KDR) pathway and prognosis. Gynecol. Oncol. 2006, 103, 912-918. [CrossRef]

214. Kolev, Y.; Uetake, H.; Takagi, Y.; Sugihara, K. Lactate Dehydrogenase-5 (LDH-5) Expression in Human Gastric Cancer: Association with Hypoxia-Inducible Factor (HIF-1 $\alpha$ ) Pathway, Angiogenic Factors Production and Poor Prognosis. Ann. Surg. Oncol. 2008, 15, 2336-2344. [CrossRef]

215. Koukourakis, I.M.; Giatromanolaki, A.; Sivridis, E.; Bougioukas, G.; Didilis, V.; Gatter, K.C.; Harris, A.L.; for the 'Tumour and Angiogenesis Research Group'. Lactate dehydrogenase-5 (LDH-5) overexpression in non-small-cell lung cancer tissues is linked to tumour hypoxia, angiogenic factor production and poor prognosis. Br. J. Cancer 2003, 89, 877-885. [CrossRef]

216. Koukourakis, M.I.; Giatromanolaki, A.; Sivridis, E.; Gatter, K.C.; Trarbach, T.; Folprecht, G.; Shi, M.M.; Lebwohl, D.; Jalava, T.; Laurent, D.; et al. Prognostic and Predictive Role of Lactate Dehydrogenase 5 Expression in Colorectal Cancer Patients Treated with PTK787 / ZK 222584 (Vatalanib) Antiangiogenic Therapy. Clin. Cancer Res. 2011, 17, 4892-4900. [CrossRef]

217. Kim, J.-W.; Dang, C.V. Cancer's Molecular Sweet Tooth and the Warburg Effect: Figure 1. Cancer Res. 2006, 66, 8927-8930. [CrossRef] [PubMed]

218. Firth, J.D.; Ebert, B.L.; Ratcliffe, P.J. Hypoxic Regulation of Lactate Dehydrogenase A. Interaction between Hypoxia-Inducible Factor 1 and CAMP Response Elements. J. Biol. Chem. 1995, 270, 21021-21027. [CrossRef] [PubMed]

219. Lewis, B.C.; Shim, H.; Li, Q.; Wu, C.S.; Lee, A.L.; Maity, A.; Dang, C.V. Identification of putative c-Myc-responsive genes: Characterization of RCL, a novel growth-related gene. Mol. Cell. Biol. 1997, 17, 4967-4978. [CrossRef]

220. Semenza, G.L.; Jiang, B.-H.; Leung, S.W.; Passantino, R.; Concordet, J.-P.; Maire, P.; Giallongo, A. Hypoxia Response Elements in the Aldolase A, Enolase 1, and Lactate Dehydrogenase A Gene Promoters Contain Essential Binding Sites for Hypoxia-inducible Factor 1. J. Biol. Chem. 1996, 271, 32529-32537. [CrossRef] 
221. Shim, H.; Dolde, C.; Lewis, B.C.; Wu, C.-S.; Dang, G.; Jungmann, R.A.; Dalla-Favera, R.; Dang, C.V. c-Myc transactivation of LDH-A: Implications for tumor metabolism and growth. Proc. Natl. Acad. Sci. USA 1997, 94, 6658-6663. [CrossRef]

222. Lu, R.; Jiang, M.; Chen, Z.; Xu, X.; Hu, H.; Zhao, X.; Gao, X.; Guo, L. Lactate Dehydrogenase 5 Expression in Non-Hodgkin Lymphoma Is Associated with the Induced Hypoxia Regulated Protein and Poor Prognosis. PLoS ONE 2013, 8, e74853. [CrossRef] [PubMed]

223. Dhup, S.; Dadhich, R.K.; Porporato, P.E.; Sonveaux, P. Multiple Biological Activities of Lactic Acid in Cancer: Influences on Tumor Growth, Angiogenesis and Metastasis. Curr. Pharm. Des. 2012, 18, 1319-1330. [CrossRef] [PubMed]

224. Polet, F.; Feron, O. Endothelial cell metabolism and tumour angiogenesis: Glucose and glutamine as essential fuels and lactate as the driving force. J. Intern. Med. 2013, 273, 156-165. [CrossRef]

225. San-Millán, I.; Brooks, G.A. Reexamining cancer metabolism: Lactate production for carcinogenesis could be the purpose and explanation of the Warburg Effect. Carcinogenesis 2016, 38, 119-133. [CrossRef]

226. Lu, H.; Dalgard, C.L.; Mohyeldin, A.; McFate, T.; Tait, A.S.; Verma, A. Reversible Inactivation of HIF-1 Prolyl Hydroxylases Allows Cell Metabolism to Control Basal HIF-1. J. Biol. Chem. 2005, 280, 41928-41939. [CrossRef]

227. Sonveaux, P.; Copetti, T.; De Saedeleer, C.J.; Végran, F.; Verrax, J.; Kennedy, K.M.; Moon, E.J.; Dhup, S.; Danhier, P.; Frérart, F.; et al. Targeting the Lactate Transporter MCT1 in Endothelial Cells Inhibits Lactate-Induced HIF-1 Activation and Tumor Angiogenesis. PLoS ONE 2012, 7, e33418. [CrossRef]

228. Kerbel, R.S. Tumor Angiogenesis. N. Engl. J. Med. 2008, 358, 2039-2049. [CrossRef]

229. Heiden, M.G.V.; Cantley, L.C.; Thompson, C.B. Understanding the Warburg Effect: The Metabolic Requirements of Cell Proliferation. Science 2009, 324, 1029-1033. [CrossRef] [PubMed]

230. Beckert, S.; Farrahi, F.; Aslam, R.S.; Scheuenstuhl, H.; Königsrainer, A.; Hussain, M.Z.; Hunt, T.K. Lactate stimulates endothelial cell migration. Wound Repair Regen. 2006, 14, 321-324. [CrossRef] [PubMed]

231. Fukumura, D.; Xu, L.; Chen, Y.; Gohongi, T.; Seed, B.; Jain, R.K. Hypoxia and acidosis independently up-regulate vascular endothelial growth factor transcription in brain tumors in vivo. Cancer Res. 2001, 61, 6020-6024.

232. Hirschhaeuser, F.; Sattler, U.G.; Mueller-Klieser, W. Lactate: A Metabolic Key Player in Cancer: Figure 1. Cancer Res. 2011, 71, 6921-6925. [CrossRef] [PubMed]

233. Shi, Q.; Le, X.; Wang, B.; Abbruzzese, J.L.; Xiong, Q.; He, Y.; Xie, K. Regulation of vascular endothelial growth factor expression by acidosis in human cancer cells. Oncogene 2001, 20,3751-3756. [CrossRef]

234. Xu, L.; Fukumura, D.; Jain, R.K. Acidic Extracellular pH Induces Vascular Endothelial Growth Factor (VEGF) in Human Glioblastoma Cells via ERK1/2 MAPK Signaling Pathway. J. Biol. Chem. 2002, 277, 11368-11374. [CrossRef] [PubMed]

235. Xu, L.; Fidler, I.J. Acidic PH-Induced Elevation in Interleukin 8 Expression by Human Ovarian Carcinoma Cells. Cancer Res. 2000, 60, 4610-4616. [PubMed]

236. Haaga, J.R.; Haaga, R. Acidic lactate sequentially induced lymphogenesis, phlebogenesis, and arteriogenesis (ALPHA) hypothesis: Lactate-triggered glycolytic vasculogenesis that occurs in normoxia or hypoxia and complements the traditional concept of hypoxia-based vasculogenesis. Surgery 2013, 154, 632-637. [CrossRef] [PubMed]

237. Trabold, O.; Wagner, S.; Wicke, C.; Bs, H.S.; Hussain, M.Z.; Rosen, N.; Bs, A.S.; Becker, H.D.; Hunt, T.K. Lactate and oxygen constitute a fundamental regulatory mechanism in wound healing. Wound Repair Regen. 2003, 11, 504-509. [CrossRef] [PubMed]

238. Ohgaki, H.; Kleihues, P. The Definition of Primary and Secondary Glioblastoma. Clin. Cancer Res. 2013, 19, 764-772. [CrossRef] [PubMed] 